\title{
3D BIOPRINTING: A REVIEW OF MATERIALS, PROCESSES AND BIOINK PROPERTIES
}

\section{BIOIMPRESSÃO 3D: UMA REVISÃO DE MATERIAIS, PROCESSOS E PROPRIEDADES DE BIOTINTAS}

\section{A. B. FONTES ${ }^{1, *}$, R. MARCOMINI ${ }^{2}$}

${ }^{1}$ Federal University of Juiz de Fora, Department of Production and Mechanical Engineering, Juiz de Fora, MG, Brazil

${ }^{2}$ Federal University of Juiz de Fora, Department of Production and Mechanical Engineering, Juiz de Fora, MG, Brazil ${ }^{*}$ Corresponding author. Federal University of Juiz de Fora, Department of Production and Mechanical Engineering, Juiz de Fora, Minas Gerais, Brazil, Phone: +5532 98824-0281

e-mail address: anna.fontes@engenharia.ufjf.br(A. B. Fontes).

\section{A R T I C L E I N F O}

Article history:

Received 2020-10-28

Accepted 2020-12-12

Available online 2020-12-12

\section{palavras-chave}

Bioimpressão 3D

Biotintas

Hidrogéis

Biomateriais

keywords

3D Bioprinting

Bioinks

Hydrogels

Biomaterials

\begin{abstract}
A B S T R A C T
$3 D$ bioprinting is an addictive manufacture method for $3 D$ scaffold engineering used as a $3 D$ template for cell attachment, growth and subsequent tissue formation. In this method, the "inks" used for printing are made from biomaterials that can be formulated and printed with cells added before or after the process. One of the most used biomaterials for bioinks is hydrogel due to its high water composition, biocompatibility and tailorable properties that facilitate the $3 D$ bioprinting process and provide favorable extracellular environment for cell functions. The $3 D$ bioprinting techniques are divided into extrusion, inkjet and laser-assisted printing, each requiring specific rheologic properties for a satisfactory printing process. One of the biggest challenges in 3D bioprinting is its optimization, which depends on 3D structural complexity, materials' properties and bioink development for the "bioprinting window". This work aims to review the state of the art of hydrogels' most common classifications and materials, the physics of each bioprinting technique and the properties affecting printability and cell viability.
\end{abstract}




\section{INTRODUCTION}

LANGER and VACANTI (1993) have described Tissue Engineering as "an interdisciplinary field that applies the principles of engineering and life sciences toward the development of biological substitutes that restore, maintain, or improve tissue function or a whole organ". (LANGER; VACANTI, 1993) Tissue Engineering and Restorative Medicine aim to study the complete restoration of damaged or degenerated tissues and organs. This multidisciplinary field has been perfecting countless methods for tissue replacement and implementation strategies with a focus on tissue and organ development for transplants. Among biomaterials development, stem cell separation, growth factors, and cellular differentiation, one of the biggest challenges in TE is 3D bioprinting's optimization, which depends on 3D structural complexity and materials' mechanical stability. (ZAVAN et al., 2009)

Two main approaches are utilized to produce tissue. The first uses scaffolding as a cell support device, which serves as a temporary extracellular matrix (ECM) until the deposited cells produce the matrix and, finally, neo-tissue replaces the scaffold. (JIN; DIJKSTRA, 2010) The second approach uses the scaffold as a growth factor/drug delivery device, combining scaffold and growth factors to recruit cells from the body to the scaffold site and form tissue throughout the matrices. (HOWARD et al., 2008)

Both approaches require the use of a porous, bioresorbable scaffold serving as a 3D template for cell attachment and subsequent tissue formation, both in vitro and in vivo. According to Hutmacher et al.: "a scaffold should have the following characteristics: (i) be highly porous with an interconnected pore network for cell growth and flow transport of nutrients and metabolic waste; (ii) be biocompatible and bioresorbable with controllable degradation and resorption rates to match tissue replacement; (iii) have suitable surface chemistry for cell attachment, proliferation, and differentiation; and (iv) have mechanical properties to match those of the tissues at the site of implantation". (HUTMACHER et al., 2001)

The engineering of 3D scaffolds involves addictive manufacture called 3D bioprinting, which has different printing methods. In this method, the "inks" used are biomaterial inks and bioinks. According to Groll et al., biomaterial inks are defined as "(bio-)materials that can be printed and subsequently seeded with cells after printing, but not directly formulated with cells" and bioinks are defined as "a formulation of cells suitable for processing by an automated biofabrication technology that may also contain biologically active components and biomaterials". (GROLL et al., 2019)

To be competent as a bioink, a biomaterial should act as a cell-laden medium/matrix during the formulation and printing. Bioinks for 3D bioprinting may contain hydrogels, hydrogel precursors, decellularized matrices, separate cells, cell microcarriers, cell/tissue spheroids, mini/tissues, organoids, or bioactive molecules. Hydrogels are considered the most outstanding class of biomaterials for bioinks due to their tailorable properties that facilitate the $3 \mathrm{D}$ bioprinting process and provide a favorable extracellular environment for various cell functions. (LI et al., 2020)
This work aims to review the state of the art of hydrogels most common classifications and materials, the physics of each bioprinting technique and the properties affecting printability and cell viability. For this objective, the research focused on articles published from 2010 to 2020 using sources such as Google Scholar, Mendeley, SciElo and ScienceDirect.

\section{HYDROGELS}

The term hydrogel refers to crosslinked, threedimensional polymer networks insoluble in water according to their crosslinking method. (ZAVAN et al., 2009) Hydrogels are composed of tridimensional polymer networks with significant quantities of water in their composition. Consequently, they are soft materials, flexible and humid with a large range of applications. Their high water composition makes them compatible with live tissues and their viscoelastic properties minimize possible damages to surrounding tissues during implantation. Additionally, hydrogels' mechanical properties are similar to soft tissues', rendering them ideal for TE. These new bioactive materials are capable of interacting with original tissues, assisting and facilitating the healing process, and imitating organs' functional and morphological characteristics.

Among materials used for applications in Tissue Engineering, the good biocompatibility, low interfacial tension and the ability to retain large quantities of water have guaranteed increasing attention to hydrogels and their properties. (ZAVAN et al., 2009) Hydrogels have been used as tissue-engineering scaffolds because they can provide a soft tissue-like environment for cell growth and allow diffusion of nutrients and cellular waste through the elastic network. The advantages over other types of polymeric scaffolds are easy control of structural parameters (swelling ratio, volume, molecular weight, and network mesh size), high water content, and adjustable scaffold architecture. The control of the hydrogel network structure allows the proper design and characterization of the degradation of scaffolds, diffusion of bioactive molecules, and migration of cells through the network.

In order to define the network structure of hydrogels, four swelling parameters have been used: the swelling ratio (Q), including the mass swelling ratio (equation 1) and the volume swelling ratio (equation 2); the polymer volume fraction in the swollen state (equation 3); the average molecular weight between crosslinks (equation 4); and the network mesh size (equation 5).

$$
\begin{aligned}
& Q_{m}=\frac{\left(W_{g}-W_{p}\right)}{W_{p}} \\
& Q_{v}=\frac{V_{g}}{V_{p}}=\left(Q_{m}+1\right) \rho_{2} / \rho_{1} \\
& v_{2, s}=\frac{V_{p}}{V_{g}}=Q_{v}^{-1} \\
& M_{c}=\frac{M_{0}}{2 X} \\
& \xi=v_{2 . s}^{-1 / 3}\left(r_{0}^{2}\right)^{1 / 2}=Q_{v}^{1 / 3}\left(r_{0}^{2}\right)^{1 / 2}
\end{aligned}
$$

Where $\mathrm{Wg}$ is the swollen gel weight in the equilibrium state, $\mathrm{Wp}$ is the polymer weight, $\mathrm{Vp}$ is the polymer volume, $\mathrm{Vg}$ is the equilibrium swollen gel volume, $\rho 1$ is the solvent density, 
$\rho 2$ is the polymer density, $\mathbf{M}_{0}$ is the polymer molecular weight, $\mathrm{X}$ is the degree of crosslinking and $\left(r_{0}^{2}\right)^{1 / 2}$ is the root-meansquare end-to-end distance of network chains between two adjacent crosslinks in the equilibrium state. The swelling ratio (Q) and the polymer volume fraction in swollen state (v2.s) can be measured from swelling experiments, while the average molecular weight between crosslinks (Mc) and the network mesh size $(\xi)$ can be calculated by rubber elasticity theories or equilibrium swelling. (ZHU; MARCHANT, 2011)

\subsection{Classification}

2.1.1 Preparation method: Hydrogels can be classified by their polymeric composition. The preparation techniques can lead to different formations such as homopolymeric, copolymeric and multipolymeric hydrogels. Homopolymeric hydrogels are referred to polymer networks derived from a single species of monomer. Copolymeric hydrogels are derived from more than one type of monomer, and multipolymeric hydrogels are derived from more than one type of polymer. Another classification is known as interpenetrating polymer (IPN), which consists in a second polymer network polymerized around and within a first polymer network with no covalent linkage between the two networks. (GARG et al., 2016; PALEOS, 2012)

2.1.2 Formation and structure maintenance: The polymer chains of a hydrogel are interconnected (crosslinked). It plays a major role in modifying the properties of polymer hydrogels in terms of absorption and mechanical properties. The amount of crosslinking agent influences the crosslinking degree, absorption capacity, swelling properties, elastic modulus etc. (KUO; MA, 2001; MAITRA; SHUKLA, 2014; PALEOS, 2012) Crosslinking affects: i) elasticity, in which the increase of crosslinks decreases the polymer stretching, also decreasing elasticity; ii) viscosity, in which the increase of crosslinks restricts polymer chain flow and decreases viscosity; iii) insolubility. The stronger the bonds in crosslinks, the more insoluble the polymer. Crosslinked materials cannot dissolve in solvents, but can absorb solvents, becoming gels. There are two types of crosslinking: physical crosslinking and chemical crosslinking.

2.1.2.1 Physical crosslinking: Physically crosslinked hydrogels, or reversible gels, are popular due to their relative ease of production and the advantage of not using crosslinking agents during synthesis, which affects toxicity and cell viability. Due to difficulties in decoupling variables such as gelation time, pore size and degradation time, the design flexibility of physically crosslinked hydrogels is restricted. Despite not being permanent in nature, physical crosslinks are sufficient to prevent gel dissolution. There are various methods used in order to obtain physical crosslinks in hydrogels, such as freeze-thawing methods, stereocomplex formation, ionic interactions, $\mathrm{H}$ bonding and maturation. (HASSAN; PEPPAS, 2000; SLAUGHTER et al., 2009; TSUJI et al., 1991; ZHANG et al., 2016a; ZHAO et al., 2009)

2.1.2.2 Chemical crosslinking: Chemically crosslinked hydrogels, or permanent hydrogels, are known for being formed relatively fast, being stable and having covalent bonds between different polymer chains. They cannot be dissolved in any solvents unless their covalent crosslink points are cleaved. Chemical crosslinking results in relatively high mechanical strength and extended degradation times. Some chemical crosslinking agents can be toxic to cells, impacting cell viability.
There are various methods used in order to obtain chemical crosslinks in hydrogels, such as chemical crosslinking, grafting, radical polymerization, enzymatic reactions and high-energy radiation. (ATHAWALE; LELE, 1998; HENNINK; VAN NOSTRUM, 2002; SLAUGHTER et al., 2009; SPERINDE; GRIFFITH, 1997; ZHAO et al., 2003)

2.1.3 Environmental response: Hydrogels with environmental response are called "smart materials" and are classified according to their sensitivity to temperature, $\mathrm{pH}$, electric, etc.

2.1.3.1 Thermo-sensitivity: Thermo-sensitive hydrogels are defined by their ability to swell and shrink according to temperature changes in the surrounding fluid. It can be classified in three categories.

Negative temperature hydrogels behave following a parameter called low critical solution temperature (LCST). At temperatures lower than LCST, the fluid interacts with the hydrogel's hydrophilic part forming hydrogen bonds, which improves dissolution and swelling. As the temperature increases above LCST, the hydrophobic part will have stronger interactions while hydrogen bonds will become weaker, causing shrinking and discharge of the previously absorbed fluid. (QIU; PARK, 2001)

Positive temperature hydrogels behave following a parameter called upper critical solution temperature (UCST). At temperatures lower than UCST, the hydrogel shrinks and dehydrates due to the formation of complex structure by hydrogen bonds. At temperatures above UCST, the hydrogen bonds break and the hydrogel suffers swelling. (PEPPAS et al., 2000)

Thermo-reversible hydrogels have the same structure and contents as negative and positive temperature hydrogels. The polymer chains, however, are not covalently crosslinked, and the gel undergoes sol-gel phase transitions instead of swellingshrinking transitions. (QIU; PARK, 2001)

2.1.3.1 $\mathrm{pH}$-sensitivity: $\mathrm{pH}$-sensitive hydrogels respond to $\mathrm{pH}$ changes of the surrounding medium, exhibiting swelling or shrinking according to it. The behavior occurs due to changes in the hydrophobic-hydrophilic nature of chains or due to hydrogen bonds. Anionic hydrogels undergo swelling when the pKa is higher than the surrounding $\mathrm{pH}$, while cationic hydrogels undergo swelling when the $\mathrm{pKb}$ is higher than the surrounding pH. (LAFTAH et al., 2011; PEPPAS et al., 2000)

\section{MATERIALS}

In order to enable cells to both get necessary nutrients for growth and metabolic activity during tissue regeneration, the bioinks used in 3D bioprinting processes must show important properties and characteristics, such as printability, mechanical properties, controlled biodegradability, non-toxicity to cells and mechanical properties. (HOSPODIUK et al., 2017)

Hydrogel materials employed for 3D cell culture can be divided into promoting and permissive materials. Promoting materials indicate that they present natural binding sites cells can interact with, generating signaling cascades which in turn promotes cell migration, differentiation and remodeling of the 
gel matrix through the secretion of proteases and enzymes. Permissive materials indicate that their properties allow for basic cell functions, but do not provide cues to direct cellular interactions. (SALINAS; ANSETH, 2009)

Naturally occurring hydrogel precursors are considered promoting materials since they allow for complex cell-matrix interactions that are also common for native cell tissues and, so, do not require further functionalization. As the focus in the design of artificial extracellular matrix (ECM), hydrogels change towards highly customized cell matrices, fully natural materials cannot provide selective behavior since material stiffness, cell-matrix interactions and degradability are often coupled and cannot be individually studied or tuned. (MARKLEIN; BURDICK, 2010)

Synthetic polymers are considered permissive materials since they usually do not present natural binding sites for cell to probe their extracellular surroundings. It is necessary to incorporate integrin ligands in the matrix for cell adhesion and spreading. (HERN; HUBBELL, 1998) In the absence of such ligands, some cells can excrete their own ECM to provide adhesion sites, otherwise spreading becomes restricted and eventually lead to cell death. (FRISCH; FRANCIS, 1994; KÖLLMER et al., 2012)

The comparison between polymers obtained as biomaterials from natural resources or synthetic materials has been the focus of various researches. While natural materials present advantages related to the biomimicking of ECM composition and structure such as biocompatibility and biodegradation, synthetic materials provide advantageous properties such as controllability of mechanical stability, photocrosslinking ability, $\mathrm{pH}$ and temperature responses, as well as the controllability of molecular weight, degradability and structures, which directly determine gel formation, crosslinking density and mechanical properties. (GOPINATHAN; NOH, 2018)

\subsection{Natural Materials}

3.1.1 Alginate: Alginate is a type of anionic polysaccharide mostly present in brown algae. It is composed of a linear chain with two possible present blocks: G-blocks ((1-4) $\alpha$-guluronate units) and M-blocks ( $\beta$-D-mannuronate units) with alternate segments of M-G blocks. The existence of these blocks and their ratio on the main chain varies from each source and influence the hydrogel's resulting properties. (MCHUGH, 1987)

Only the G-blocks are believed to participate in intermolecular crosslinking with divalent cations to form hydrogels. The M/G ratio, sequence, G-block length and molecular weight are critical factors affecting physical properties of alginate and its resultant hydrogels. The mechanical properties are typically enhanced by increasing the G-block length and molecular weight. However, an alginate solution formed from high molecular weight polymer becomes greatly viscous, which is often undesirable. Cells mixed with an alginate solution of high viscosity risk damage from the high shear forces generated during mixing and processing. (LEE; MOONEY, 2012)

Alginate hydrogels have shape-memory capability, biocompatibility, ability of degradation, nun-immunological effects, improved porosity and mechanical strength. (JANG et al., 2014) The rheological properties of alginate allow a shearthinning behavior, reducing viscosity under shear stress. This characteristic is favorable for extrusion printing and cell survivability during the process. (WANG et al., 1994).

3.1.2 Agarose: It is a marine polysaccharide obtained from seaweed. It is highly used in the biomedical field due to its gelation properties, biocompatibility and rheological properties. (JAKUS et al., 2016) The gelling mechanism of agarose resides in the formation of intermolecular hydrogen-bonds upon cooling, resulting in the aggregation of double helices. Though the gelation, mechanical and biocompatibility properties of agarose are commendable, its ability to support cell growth is limited. (FEDOROVICH et al., 2008)

Its viscoelastic properties strongly depend on the desulfation degree and the local strength of the network is sensitive to the length of the molecules. Depending on its molar mass and solution concentration, agarose can form physical gels with tunable elastic moduli ranging from $\sim 1 \mathrm{kPa}$ to a few thousand $\mathrm{kPa}$, in the stiffness range of natural tissues. (NORMAND et al., 2000)

In general, its viscous nature does not allow inkjet bioprinting as it can easily clog the nozzle. It is, however, a promising candidate for laser-based bioprinting due to its viscoelastic nature and gelation mechanism. It has been deposited using LIFT processes, fully maintaining high cell viability. (KOCH et al., 2010)

3.1.3 Collagen: Collagen is a triple helical biocompatible protein obtained from natural sources which has been extensively used in bioprinting. It is the main component of ECM and one of the major components of connective tissues, occupying about $25 \%$ of the protein mass in most mammals. Its conservation cross-species allows for minimal immunological reactions and thus excellent biocompatible properties. Its matrix facilitates cell adhesion and enhances cell attachment and growth due to abundant integrin-binding domains. (FERREIRA et al., 2012)

Despite its uses in bioprinting, collagen has its limitations due to its liquid state at low temperatures and fibrous structures formed with increased temperature or $\mathrm{pH}$. Complete collagen gelation can take up to 30 minutes at $37{ }^{\circ} \mathrm{C}$, which marks a slow gelation rate and makes bioprinting of $3 \mathrm{D}$ constructs difficult. Due to its slow gelation, cells deposited in collagen are not homogeneously distributed, since gravity pulls down the cells before gelation. (SMITH et al., 2004)

Low mechanical properties and slow gelation issues make it necessary for the addition of different polymers in various proportions. For example, cartilage tissue engineering often use a combination of collagen and alginate. (YANG et al., 2018)

Collagen has been utilized alone as bioink in extrusionbased bioprinting. (SMITH et al., 2004) Droplet-based bioprinting also has an advantageous use in collagen; however, it needs to be deposited before the crosslinking onset. (DEITCH et al., 2008) Due to its fibrous structure, the collagen use in inkjet bioprinting is highly limited, with micro-valve bioprinting being preferred. (SKARDAL et al., 2012)

3.1.4 Hyaluronic acid: It is one of the major extracellular 
matrix (ECM) components in a variety of tissues such as central nervous system, cartilage, synovial and vitreous fluids and connective, epithelial and cardiovascular tissues. It is involved in several biological functions, such as regulation of cell adhesion, cell motility, cell differentiation and proliferation, and providing mechanical properties to tissues. HA is also responsible for providing the viscoelasticity of some fluids. (KHANSARI et al., 2017)

As a naturally occurring polymer, $\mathrm{HA}$ is biocompatible, biodegradable non-adhesive, non-thrombogenic and nonimmunogenic, presenting unique viscoelasticity resulting from entanglement and self-association of random coils in solution. It can self-associate and also bind to water molecules, giving it a stiff, viscous quality similar to gelatin. (CAMCI-UNAL et al., 2013; HEMSHEKHAR et al., 2016)

Like other natural polymers, HA has low mechanical properties and slow gelation behavior when compared to synthetic hydrogels. HA is also highly soluble at room temperature and has a high rate of elimination and turnover depending on its molecular weight and body location, which could be a barrier for HA scaffold fabrication and structural integrity. (FAKHARI; BERKLAND, 2013; GOPINATHAN; $\mathrm{NOH}, 2018$ )

In order to increase rheological properties of HA, crosslinking methods have been introduced for tissue engineering applications. Crosslinking extends HA degradation process in vivo and provides long-term stability, with Photocrosslinked hydrogels used for cartilage tissue engineering. Chemical crosslinking has been used to combine desirable biological and mechanical properties for bone tissue engineering, presenting difficulties such as potential toxicity due to certain crosslinking agents. (ALLISON; GRANDE-ALLEN, 2006; WEBER et al., 2019)

3.1.5 Fibrin: Fibrin is a naturally occurring protein-based material which has been used as a sealant and adhesive in surgery, playing a significant role in injure healing, modifications and fabrications of skin graft, cardiovascular treatments and cartilage engineering. (AHMED et al., 2008; SKARDAL et al., 2012) It can be produced from the patient's own blood, which reduces the potential risk of a foreign body reaction. (JOCKENHOEVEL et al., 2001)

In comparison to most commonly used scaffolds, fibrin gel combines important advantages, such as nonimmunogenicity, excellent biocompatibility properties, soft elasticity, self-assembly features under physiological conditions by the activation of fibrinogen, and naturally present cell binding sites. (DES RIEUX et al., 2009; GOPINATHAN; NOH, 2018; JANMEY et al., 2009; RAJANGAM; AN, 2013) The fibrin fiber is one of the most extensible of filamentous biopolymers, resisting stretching more than five times its resting length without breakage, with even elongational strains greater than $100 \%$ being recoverable when the stress is released. The high degree of deformation tolerated by the fibrin is in part due to very loose monomers packing and high water content, making for softness and large compliance essential for its efficiency as a matrix for cells such as neurons. (JANMEY et al., 2009)

The fibrin hydrogel as a potential scaffold has three major disadvantages: i) gel shrinkage during the formation of flat sheets; ii) low mechanical stiffness; and iii) fast degradability before the proper formation of engineered tissues and structures. (JOCKENHOEVEL et al., 2001; MOL et al., 2005; ZHAO et al., 2013)

The first disadvantage can be prevented by incorporating a fixing agent. (JOCKENHOEVEL et al., 2001) Mechanical stability can be improved with numerous strategies: i) combining fibrin with other scaffold materials to obtain constructs with the desired mechanical strength (GALLER et al., 2011; MOFFAT et al., 2009; RAHEJA et al., 2011; WANG et al., 2011), ii) optimizing $\mathrm{pH}$ and the concentrations of fibrinogen and calcium ion (EYRICH et al., 2007), and iii) using fibrin microbeads (FMB), a highly crosslinked, dense, and 3D fibrin matrix. (RIVKIN et al., 2007) Fibrin's fast degradability can be prevented by reducing cell density. (DIKOVSKY et al., 2006)

3.1.6 Gelatin: Gelatin is a water soluble and biodegradable polypeptide derivative of collagen commonly used for pharmaceutical and medical applications. (YOUNG et al., 2005) There are two types of gelatin: gelatin A, which is prepared by acidic treatment before thermal denaturation, and gelatin B, which is prepared by alkaline treatment.(LEE; MOONEY, 2001)

Their gelling properties depend on both the hydrolytic treatment methods and the source origin, such as bones, skin and connective tissues of animals. Mammalian derived gelatins from swine and bovine sources have similar polypeptide structures with human beings, while fish derived gelatins have a lower content of polypeptides in their polypeptide chains, resulting in significantly lower melting point, lower gelling temperature, lower thermal stability and higher viscosity. (WANG et al., 2017)

Due to the possible differences in origin, pretreatment methods and processing parameters, the average molecular weight of gelatin varies between 15,000 and 400,000 Daltons, showing gelatin's molecular heterogeneity as one of its major limitations. (FOOX; ZILBERMAN, 2015; OLSEN et al., 2003) Much like collagen, gelatin presents poor mechanical properties, making its viability dependent on the addition of crosslinking agents. The use of chemical crosslinking agents, such as aldehydes, requires caution due to their toxicity, which can greatly damage cells. Physical crosslinking, such as addition of methacrylate or photopolymerization, improves the composite viscosity and its mechanical properties.

Several features present in gelatin make it a desirable material, such as biocompatibility, biodegradability and lower immunogenicity when compared to collagen, as well as its porous structure which results in solubility and transparency. (KHANSARI et al., 2017; SU; WANG, 2015)

\subsection{Synthetic Materials}

While natural polymers offer favorable environments similar to native ECM for tissue engineering applications, synthetic materials can be adapted according to the requirements of bioprinting processes. They can be chemically modified with crosslinkable functional groups, but also with groups capable of enhancing structural and mechanical properties, enabling one to carefully engineer the polymer design. (HOSPODIUK et al., 2017) 
3.2.1 Methacrylated gelatin (GelMA): Methacrylated gelatin, or GelMA, is the denatured form of collagen consisting of methacrylate groups conjugated to its amine side groups. It has been used for tissue engineering due to its adjustable mechanical characteristics and favorable biological properties. (BENTON et al., 2011; NICHOL et al., 2010)

Its advantageous features include relatively high mechanical strength, low swelling ratio, bioprintability, longterm biocompatibility, low viscosity at room temperature, manipulatable crosslinking rate by exposure to UV light length. It is also easy to extrude, is amenable to blending with other biogels and forms a biomimetic and enzymatically degradable hydrogel when photo-crosslinked. Its major disadvantages are low cell proliferation and possible cell damage due to its photocrosslinking necessity. (HOSPODIUK et al., 2017; HUTSON et al., 2011)

3.2.2 Poly(ethylene glycol) (PEG): In synthetic polymers, poly(ethylene glycol) (PEG) and Pluronic are the most commonly used polymers in 3D bioprinting. PEG exhibits high hydrophilicity, greater mechanical stiffness compared to naturally-derived polymers, water solubility, biocompatibility and very minimal immunogenicity, making it an attractive material for 3D scaffold designs. Its properties can be tuned as per requirements through variation of its chemistry, crosslinking and combination with polymers such as alginate and collagen. (ABELARDO, 2018; GAO et al., 2015; HONG et al., 2015; RUTZ et al., 2015)

PEG-based hydrogels have been widely used in bioprinting. Poly(ethylene glycol) diacrylate (PEG-DA) and poly(ethylene glycol) methacrylate (PEG-MA) hydrogels are specially used in all types of bioprinting: extrusion-based bioprinting (EBB) (BERTASSONI et al., 2014; HOCKADAY et al., 2012; SKARDAL; ZHANG; PRESTWICH, 2010; WÜST; MÜLLER; HOFMANN, 2015), droplet-based bioprinting (DBB) (CUI et al., 2012) and laser-based bioprinting (HRIBAR et al., 2014).

Addition of DA and MA can be highly beneficial to PEG mechanical properties; however, they require photocrosslinking by UV light exposure for specific lengths of time, which can reduce cell viability. Another disadvantage is that PEG does not form hydrogel on its own and needs chemical modification to form cross-linked strands and 3D structure. (ABELARDO, 2018)

PEG is not degraded naturally, which makes it necessary to incorporate degradable segments to accelerate degradation, such as poly(lactic acid), poly(glycolic acid) and PCL, all known to degrade by hydrolysis. (ABELARDO, 2018) As any other synthetic polymer, PEG-based hydrogels lack the necessary biologic attachments for cellular interaction, which makes it necessary to tether bioactive molecules to its strand in order to mimic cell-matrix adhesions and carry signaling cues. (LUTOLF et al., 2003)

3.2.3 Pluronics: PEG-poly(propylene oxide) or so called poloxamers are commercially known as Pluronics. There are 11 types of Pluronic polymers which differ by molar mass, composition, functionality and crosslinking temperature which can vary from $10{ }^{\circ} \mathrm{C}$ to $40{ }^{\circ} \mathrm{C}$. (WANG; LEE; YEONG, 2015)
The advantage of Pluronic is mainly due to is ability to form self-assembling gels at room temperature. It can flow at $10{ }^{\circ} \mathrm{C}$, undergoing reverse gelation, with crosslinking starting with increasing temperature. (KANG et al., 2016) It can maintain cell viability for up to 5 days without any additives, with a dramatic decrease thereafter. Its mechanical strenght increases with enzymatic crosslinking and it does not lose its thermally-reversible properties. It can be chemically crosslinked in order to increase its thermal degradation resistance. (MASUTANI et al., 2014)

In extrusion-based bioprinting, acceptable bioprintability using Pluronic is obtained above $20{ }^{\circ} \mathrm{C}$ as it becomes more viscous and exhibits shear-thinning behavior. Depending on its concentration, Pluronic requires a heating system around the needle in order to transition from liquid to gel state and a heated plate to maintain the construct temperature after deposition. It is more advantageous to maintain it in a semiliquid state in order to preserve cell viability. In droplet-based bioprinting, its high viscosity and thermosensitive nature are problematic. Laserbased bioprinting has not been successful as Pluronic is not viscoelastic, maintains a solid coating on the quartz support and cannot transfer thermal energy to kinetic energy, which is essential for jet formation. (HOSPODIUK et al., 2017)

Pluronic copolymer structures erode quickly and cannot hold structural integrity for longer than a few hours. Strategies to increase mechanical strength include crosslinking using methylacrylate and UV light. However, their mechanical strenght remains poor, the radiation type and duration can impact cell viability and the concentration of photo-initiator can affect cell metabolism. (JOHNSON, 2011; MÜLLER et al., 2015)

3.2.4 Poly(vinyl alcohol) (PVA): PVA is prepared from the partial hydrolysis of poly(vinyl acetate). It can be crosslinked into a gel through chemical of physical methods and, as an alternative, can be photocured to fabricate hydrogels. Its structure has groups that function as attachment sites for biological molecules that can be enhanced, induce cell orientation and has properties similar to natural cartilage, making PVA a successful material for avascular tissue. (MILLON et al., 2012; ZHANG et al., 2015a)

Another advantage of PVA is its tunable properties. By adjusting molecular weight, crosslinking points and extent of hydrolysis, it is possible to control degradation time, swelling rate, hydrophilicity and solubility. (SCHMEDLEN et al., 2002)

Some disadvantages include toxicity and leaching problems of chemical crosslinking agents, which can impact cell viability. PVA is not degradable in most physiological situations, making it necessary to apply strategies such as placing degradable groups between the PVA chain and the crosslinkable group in order to render it biodegradable. (HOSPODIUK et al., 2017; SCHMEDLEN et al., 2002) PVA can also be copolymerized with PEG to produce a biodegradable hydrogel with degradation rate faster than PEG hydrogels and slower than PVA homopolymer hydrogels. (ZHANG et al., 2015a)

\section{3D BIOPRINTING}

3D printing is an additive manufacture technique 
implementing layer-by-layer production of structures. This was made possible by combining other technologies, such as computer aided design (CAD), computer aided manufacture (CAM) and computer numerical control (CNC). Firstly, a 3D model of the desired structure is made through CAD, saved as a .stl file and processed through the software used for 3D printing. (WONG; HERNANDEZ, 2012)

The 3D bioprinting systems can be divided in techniques based in extrusion, inkjet and laser-assisted bioprinting as shown in Figure 1. Each method has its specific requirements for bioinks' rheological properties.

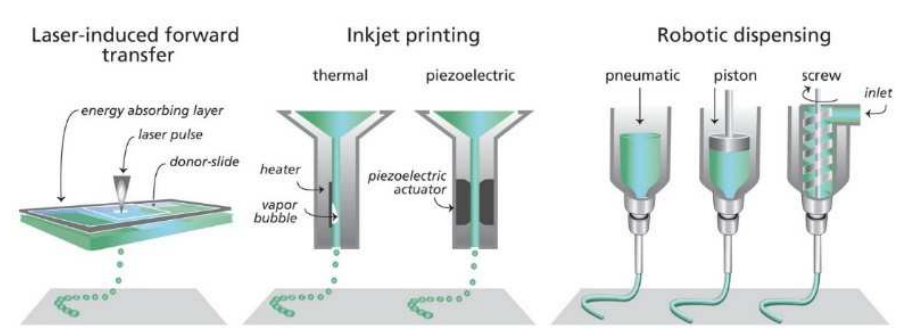

Figure 1 - Biofabrication methods involving bioinks. (MALDA et al., 2013)

\subsection{Extrusion Based Bioprinting}

Bioinks used in this method are generally viscous hydrogels, containing cells or not, forced through a nozzle mechanically or pneumatically (Figure 2). The nozzle is moved at a specified height over the substrate or preceding layer of material as the bioink is dispensed. The resulting flow of bioink has a physical form which depends on the hydrogel's rheological properties and bioprinting dispensing condition such as nozzle diameter (D), dispensing height $(\mathrm{h})$, translation speed $(\mathrm{F})$, volumetric flow rate $(\mathrm{Q})$ and adhesion to the substrate or preceding layer.
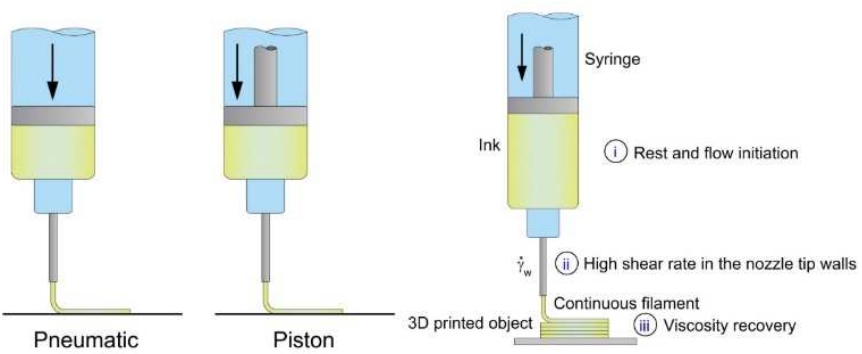

Figure 2 - Dispensing methods for extrusion-based bioprinting. (DERAKHSHANFAR et al., 2018)

The dispensing conditions impact quality of the print, cell viability and total print time. The nozzle diameter impacts printing resolution and printing speed due to its size. The dispensing height impacts the height of each layer above the receiving surface and its alteration impacts the number of layers and cross-sectional shape of the dispensed material. The translation speed impacts the nozzle speed relative to the substrate.

Bioinks can vary in physical form depending on hydrogel and cellular components' concentrations. The goals for extrusion printing are to reach stable, stackable filaments in a highly repeatable and predictable process and understand the interactions between bioink properties and extrusion parameters so the designed outcome is reached. (SHAFIEE et al., 2019)

Extrusion dynamics are usually modeled with hydrogels derived from alginate, alginate/gelatin and other materials that can produce reliable and repeatable results with high shape fidelity. (HE et al., 2016) Despite these materials have provided a better understanding of influencing factors for the bioprinting process, these hydrogels have specific limitations that do not represent all materials.

The extrusion bioprinting process require important characteristics including dynamic viscosity, loss modulus and storage modulus. Cell viability is preserved with the control of shear stress and applied pressure. For that reason, it is important to understand the relationships between flow rate, shear stress, applied pressure, moduli and viscosity.

Few materials utilized in bioprinting processes can be classified as Newtonian fluids, so most bioinks are not modelled following classical relationships. In order to simplify calculations and estimations, or for materials with properties close to Newtonian, the equations for Newtonian fluids are useful due to the direct and linear relationship between an imposed force and the resulting flow, resulting in a constant viscosity at a given temperature and atmospheric pressure. NonNewtonian fluids have viscosity as a function of the imposing force, resulting in a complex relationship between the imposing force and the resulting fluid flow.

For a Newtonian fluid in laminar flow conditions, the Hagen-Poiseuille equation relates volumetric flow rate $(\mathrm{Q})$ to the pressure applied $(\mathrm{P})$ to a nozzle (length $\mathrm{L}$ and diameter $\mathrm{d}$ ) and viscosity $(\eta)$ and can be used to estimate the bioink viscosity: (TRACHTENBERG et al., 2014)

$Q=\frac{\pi \Delta P}{128 L \eta} d^{4}$

Successful models can be built to relate the nozzle crosssection area (A), flow velocity (v) and time (t) to flow rate (Q) by combining the Hagen-Poiseuille equation with conservation of volume (V): (OUYANG et al., 2016a)

$V=A v t=Q t$

The shear stress $(\tau)$ in Newtonian fluid flow is linearly related to the shear rate $(\dot{y})$ or the velocity gradient by the material viscosity $(\eta)$ :

$\tau=\eta \dot{y}$

The shear rate for Newtonian fluids can be related to the nozzle internal radius $(\mathrm{R})$ and the average flow velocity $(\bar{v})$ :

$\dot{\mathrm{y}}=\frac{4 \bar{v}}{R}$

The shear stress cannot be expressed in terms of constant viscosity (as seen on Eq. (2)) for non-Newtonian fluids as apparent viscosity becomes a function of shear rate. With the increase of shear rate, viscosity tends to decrease, which is a common behavior among non-Newtonian fluids and aqueous mixtures of biomaterials called shear thinning. Therefore, applying the above equations for Newtonian fluids to bioinks with obvious shear thinning behavior may ensue misleading results. 
The Power Law better relates the apparent viscosity $(\eta)$ and the shear rate $(\dot{\mathrm{y}})$ with the viscosity factor $(\mathrm{K})$ and the shear thinning factor $(\mathrm{n})$, representing a simple model to understand the complex relationship between shear rate and shear stress in non-Newtonian fluids. (JUNGST et al., 2016)

$\tau=K \dot{y}^{n}$

The Power Law equation also allows the determination of shear stress and velocity profile across the nozzle radius and average extrusion velocity. (SKARDAL et al., 2012) Shear stress $\left(\tau_{\mathrm{r}}\right)$ and fluid velocity $(\mathrm{v})$ are functions of the distance $(\mathrm{r})$ along the nozzle radius $(\mathrm{R})$ :

$\tau_{r}=\frac{r \Delta P}{2 L}$

$v=\frac{n}{n+1}\left(\frac{\Delta P}{2 L K}\right)^{\frac{1}{n}}\left(R \frac{n+1}{n}-r \frac{n+1}{n}\right)$

$\bar{v}=\left(\frac{-\Delta P}{2 L K}\right)\left(\frac{n}{3 n+1}\right) R^{\frac{n+1}{n}}$

Many of the necessary properties to evaluate bioink printability are complex due to the non-Newtonian nature of certain hydrogels and bioinks. Many of the relevant parameters have ranges within which extrusion is still possible and printability is considered acceptable, but there isn't a consensus on what defines ideal printability. One of the approaches used in order to determine extrusion quality is to evaluate relevant parameters post bioprinting, such as filaments consistency, filament cross-section, cross-hatch lattice quality and stacking ability. (HE et al., 2016; OUYANG et al., 2016a, 2016b)

Since material properties are strongly dependent on flow conditions, the evaluation simply based on material properties to predict printability is a flawed approach. An alternative to this approach is to relate resulting filament properties to the material's rheological dynamic moduli. (GAO et al., 2018) Gao et al. defined viscosity in terms of loss modulus (G'), storage modulus $\left(G^{\prime}\right)$ and the material loss tangent $(\tan \delta)$ to determine a range in which good printability was indicated.

$\eta=\frac{\left({G^{\prime}}^{2}+G^{\prime \prime 2}\right)^{1 / 2}}{y^{\prime}}$
$\operatorname{tg} \delta=\frac{G^{\prime \prime}}{G^{\prime}}$

In mechanical extrusion, the material flow is caused by volumetric displacement generated by a piston or screw. Due to mass conservation, the piston velocity can be directly related to extrusion velocity by the ratio of cross-sectional areas. The required time for the extruder to generate enough pressure to overcome the bioink yield stress requires optimization and adjustments for an appropriate extrusion process from the beginning to the end of a filament. (LIU et al., 2016)

In pneumatical extrusion, the motive force is generated by pressure difference caused by air introduction into the material reservoir. It is necessary to estimate and evaluate pressure for adequate flow rates, as low flow rates can negatively impact cell viability, while high flow rates may cause cell damage due to high shear rates. (NAIR et al., 2009)

\subsection{Inkjet Bioprinting}

There are two methods used in order to generate droplets in inkjet bioprinting: continuous inkjet (CIJ) and drop-ondemand (DOD) (Figure 3). On the CIJ method, a continuous ink jet is issued through a nozzle and is divided in a spherical droplets' flow through superficial tension forces, which make the cylindrical jet unstable (Plateau-Rayleigh instability). This instability is controlled through the application of a vibration on the flow. The droplets are individually electrically charged by induction from an electrode and are steered in flight by electrostatic forces to the indicated points on the substrate. The non-charged droplets suffer deviation and go through to a gutter in order to be recirculated. Due to the (bio-)ink recirculation and the resulting material contamination risk, the CIJ method is not used in bioprinting. (HUTCHINGS, 2010)

In the DOD method, a single droplet is generated only when required by propagating a pressure pulse by an actuator in a fluid filled chamber. The generated drop goes through the nozzle directly onto the substrate for deposition. In this method, two kinds of actuators can be used: thermal or piezoelectric. In thermal DOD, a microheater near the nozzle generates heat and vaporizes a small pocket of fluid and drives the generated bubble through the nozzle. In piezoelectric DOD, the pulse is formed by mechanical actuation of the chamber, generating pressure waves that eject fluid through the nozzle. (DERBY, 2008)

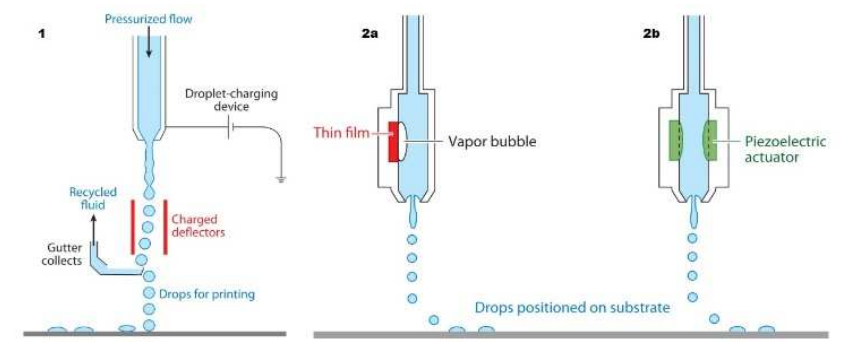

Figure 3 - Inkjet bioprinting methods: (1) continuous inkjet (CIJ), (2a) thermal drop-on-demand (DOD) and (2b) piezoelectric drop-on-demand (DOD). (DERBY, 2010)

The DOD methods, despite their differences in actuators, share parameter, concepts and equations in common. The bioink-surface interaction after droplet impact is of great importance, affecting kinematics, spreading, relaxation, wetting and equilibrium phases. (RIOBOO et al., 2001, 2002) The collision moment between drop and the surface is governed by kinematic behavior and lasts for $<1 \mu \mathrm{s}$. (DERBY, 2010) When the droplet collides with the substrate surface, six possible scenarios are possible: deposition, prompt splash, corona splash, receding breakup, partial rebound and complete rebound. Among the possibilities, only the deposition scenario is ideal for inkjet bioprinting. (RIOBOO et al., 2001)

After the kinematic phase, the droplet on the surface undergoes spreading, where it expands as far as its initial kinetic energy permits, with spreading speed increased by impact speed and droplet size and decreased by higher surface tension or higher viscosity. After the spreading phase, what follows is the relaxation phase during which the drop goes through relaxation with an oscillation in its shape on the surface and limited to the equilibrium contact angle $\theta_{\text {eq }}$. The wettability of the surface is reflected by the largest droplet diameter after spreading and the relaxation. (DERBY, 2010)

The equilibrium condition is based on the minimum of the surface energy. The contact angle may vary depending on the substrate surface and ink properties, including their energy. 
When the surface energy is too high (hydrophilic surface), the droplet tries to minimize the energy and spreads to its maximum possible distance, creating a very low contact angle; when the surface energy is too low (hydrophobic), the liquid does not spread and the droplet forms spherical shapes. The surface energy ( $y$ ) between solid (s), liquid (l), vapor (v) and the contact angle $(\theta)$ are as follow:

$y_{s v}=y_{s l}+y_{l v} \cos \theta$

The interfacial energy between liquid and vapor ( $\left.\mathrm{y}_{\mathrm{lv}}\right)$ is the surface tension of the ink. For hydrophobic surfaces, the contact angle is such that $y_{s v}=y_{s l}$ and for hydrophilic surfaces, the contact angle is so small that $y_{s v}=y_{s l}+y_{l v}$. (ISRAELACHVILI, 2011)

The droplet formation mechanisms and fluid properties are critical factors that demand study and optimization in order to obtain the desired outcomes during inkjet bioprinting. Many bioinks may satisfy biocompatibility criteria but fail the bioprinting process because they are not appropriate for inkjet printing methods.

The bioink behavior during printing (droplet size, shape and velocity) depends on the actuator utilized, therefore it is necessary to optimize it before the bioprinting process. A droplet can be ejected through the nozzle containing a tail (also known as satellite), which reduces the deposition quality on the substrate. Obtaining droplets free of satellites or containing minimum tail lengths is of critical importance in order to optimize actuator pulse. (TSAI et al., 2008)

Besides droplet shape and velocity, other important parameters must be tested before printing, such as density, viscosity and superficial tension. As a means to relate viscosity and superficial tension, the Ohnesorge number is utilized along with characteristic length (a), density $(\rho)$, viscosity $(\eta)$ and superficial tension $(y)$ :

$O_{h}=\frac{\sqrt{W_{e}}}{R_{e}}=\frac{\eta}{(y \rho a)^{1 / 2}}$

$W_{e}=\frac{v^{2} \rho a}{y}$

$R_{e}=\frac{v \rho a}{\eta}$

$Z=\frac{1}{o_{h}}$

Using the condition $1<Z<10$ and the Ohnesorge $\left(\mathrm{O}_{\mathrm{h}}\right)$, Weber $\left(\mathrm{W}_{\mathrm{e}}\right)$ and Reynolds $\left(\mathrm{R}_{\mathrm{e}}\right)$ numbers, it is possible to evaluate the stability of a droplet obtained from a bioink and its appropriateness for inkjet bioprinting. This condition presents restrictions to density, viscosity and surface tension while choosing or fabricating bioinks; for example, bioinks with low $\mathrm{Z}$ values $(<1)$ cannot be printed by inkjet methods because their viscous dissipation prevents droplet ejection, while bioinks with high $\mathrm{Z}$ values $(>1)$ produce a substantial number of unwanted satellite droplets. (DERBY, 2010)

Besides $\mathrm{R}_{\mathrm{e}}, \mathrm{W}_{\mathrm{e}}$ and $\mathrm{O}_{\mathrm{h}}$, other numbers can be considered to evaluate printing quality. The capillary number $C_{a}=\frac{\eta_{0} v}{y}$ relates viscous forces effects to superficial tension across an interface, whereas the Bond number $B_{o}=\frac{\rho g L_{0}{ }^{2}}{y}$ represents gravity effect, which can be omitted in most cases of small droplets (including inkjet printing). Both expressions relate a characteristic length $\left(\mathrm{L}_{0}\right)$, fluid velocity $(\mathrm{v})$, low-shear viscosity $\left(\eta_{0}\right)$ and gravitational constant $(\mathrm{g}) .(\mathrm{JUNG}, 2011)$

$\mathrm{W}_{\mathrm{e}}$ and $\mathrm{O}_{\mathrm{h}}$ can be used to characterize spreading dynamics. Since $\mathrm{W}_{\mathrm{e}}$ indicates the ratio of inertial to capillary forces, a high $\mathrm{W}_{\mathrm{e}}$ indicates the influential parameter in droplet spreading is impact induced inertia, while a low $\mathrm{W}_{\mathrm{e}}$ indicates capillary forces prevent the drop from spreading. $\mathrm{O}_{h}$ is based on fluid properties and can compare viscous forces with surface tension forces, with a high $\mathrm{O}_{\mathrm{h}}$ indicating that viscosity is playing a major role in drop spreading and a low $\mathrm{O}_{\mathrm{h}}$ indicating that surface tension is more dominant in spreading, which is the case for inkjet printing. (MARTIN et al., 2008)

\subsection{Laser-assisted Bioprinting}

The laser-induced forward transfer method (LIFT) consists of a laser beam facing the rear side of a ribbon (a glass side coated with a laser-absorbing layer generally made of gold, silver or titanium) coated with cellular material. The laser pulses irradiate the coating matrix, creating extremely localized heat and generating a vapor bubble that develops quickly and is expelled onto the substrate, which can be delineated in terms of the Direct Writing Height (DWH) and the breakup length. If the breakup length is smaller than or equal to the DWH, the results are droplet-impingement printing. If the breakup length is larger than the DWH, the results are jet-impingement printing, which is associated with single or several breakups. (ZHANG et al., 2016b)

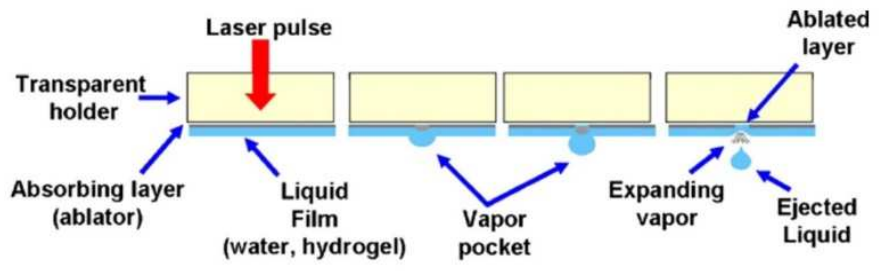

Figure 4 - Laser-induced forward transfer (LIFT) bioprinting schematic. (SHAFIEE et al., 2019)

The Weber number is determined by calculating the ratio of the liquid inertia-to-surface tension in the process of impingement. The critical Weber number $\left(\mathrm{W}_{\mathrm{ec}}\right)$ is used to designate when splashing occurs, the parameter Wet1 is used to designate the threshold for material transfer, and the parameter $\mathrm{W}_{\mathrm{et} 2}$ is used to designate the threshold for material transfer with plumming, splashing or bulgy shape. The condition for splashing on the substrate to occur can be expressed as

$W_{e} \geq W_{e c}$

$W_{e}=\frac{\rho R U^{2}}{\sigma}$

For a situation in which $\mathrm{W}_{\mathrm{e}}<\mathrm{W}_{\mathrm{et} 1}$, the pressure in the bubble is inadequate to surpass the surface tensions of the coating and the surrounding pressure; consequently, the ink material is unable to escape as a jet droplet. For a situation in which $\mathrm{W}_{\mathrm{e}}>\mathrm{W}_{\mathrm{et} 2}$, the pressure on the bubble is too high; it bursts and either splashes or forms a jet with bulgy shape. For situations in which $\mathrm{W}_{\mathrm{ec}}<\mathrm{W}_{\mathrm{e}}<\mathrm{W}_{\mathrm{et} 2}$, the splashing phenomenon becomes relentless. The optimized printing condition is anticipated to occur when $\mathrm{W}_{\mathrm{et} 1}<\mathrm{W}_{\mathrm{e}}<\mathrm{W}_{\mathrm{ec}}$. (ZHANG et al., 2016b)

In the case of laser bioprinting of alginate, it was shown 
that most of the laser input energy is expanded in the form of elastic, surface and kinetic energies to form the drops. When a droplet is created, it dissipates becomes of the amalgamation of ambient aerodynamic, capillary, elastic, liquid, inertial and viscous forces. The droplet may experience four different sorts of breakup processes: atomization, first wind-induced breakup, second wind-induced breakup, or Rayleigh breakup processes. Most droplet breakups are extrapolated to either Rayleigh or Plateau-Rayleigh instability.

During the creation of the jet, capillary thinning and breakup of free surface viscoelastic liquid filament breakup are understood over three time scales: the visco-capillary time scale $t_{v}$, the Rayleigh capillary scale $t_{c}$, and $\lambda$, where $\eta_{0}$ is the zero shear viscosity, $\mathrm{R}$ is the characteristic length considered the laser spot radius, and $\rho$ symbolizes the density in the equations 23 and 24:

$t_{v}=\frac{\eta_{0} R}{\sigma}$

$t_{c}=\left(\frac{\rho R^{3}}{\sigma}\right)^{1 / 2}$

The Ohnesorge number $O_{h}$, elasto-capillary number $E_{c}$, and Deborah number $D_{e}$ in equations (25), (26) and (27) are critical numbers to optimize the printing parameters. The prediction of droplet formation can be enhanced using the $\mathrm{O}_{\mathrm{h}}$ and $\mathrm{E}_{\mathrm{c}}$ numbers. The $\mathrm{E}_{\mathrm{c}}$ number alone is inconsequential, but the $D_{e}$ number together with its processing time is meant for fluids for which viscosity is of paramount importance. Furthermore, the Weber number is recommended as a process-dynamics figure for the apprehension of jetting dynamics. The $E_{c}$ number decreases or the $\mathrm{O}_{\mathrm{h}}$ number increases, and the alginate concentration also increases, which in turn augments the $\mathrm{W}_{\mathrm{e}}$ number.(ZHANG et al., 2015b)

$O_{h}=\frac{t_{v}}{t_{c}}=\eta_{0}(\rho \sigma R)^{1 / 2}$

$E_{c}=\frac{\lambda}{t_{v}}=\frac{\lambda \sigma}{\eta_{0} R}$

$D_{e 0}=\frac{\lambda}{t_{c}}=\left(\frac{\lambda^{2} \sigma}{\rho R^{3}}\right)^{1 / 2}$

Cell viability in laser bioprinting is related to factors such as laser energy, extracellular matrix film thickness, and the bioink viscosity. On increasing the laser energy, the viability of cells may be reduced owing to the significant denaturation of DNA by ultraviolet light; hence, an infrared laser may be preferred to ultraviolet lasers in the bioprinter framework. The respective cell viabilities can be considerably high if the laser energy conditions vary per thermal flux intensities.

The phenomenon is correlated with the numerical models, indicating that (a) the thickness of the heated liquid water during the course of a laser pulse is only a few micrometers and (b) the complete cell droplet forms in a very short period of time. The three different conditions causing mechanical stress in the laserassisted cell printing could be the hydrodynamic pressure emerging from the bubble during its budding phase, the unfolding shear stress on the account of jet velocity during the jetting phase, and the conditions of landing that are consequent to the initial jet velocity and the thickness of the mattress. Increasing bioink viscosity reduces jet velocity, minimizing impacts intensity, thus improving cell viability after printing.
The cell viability during laser bioprinting requires the optimization of bioink viscosity, film thickness and laser energy. (CATROS et al., 2011)

\section{PROPERTIES}

\subsection{Swelling}

The water holding property in a hydrogel is one of its most important characteristic features. When a dry hydrogel starts soaking water, the initial molecules moving into the matrix will hydrate the most polar, hydrophilic groups, leading to primary bound water. As the initial polar groups are hydrated, the network swells and expands, exposing hydrophobic groups and resulting in secondary bound water (hydrophobically-bound water). Due to osmotic driving forces of network chains, the network will absorb additional water tending towards infinite dilution, which is opposed by the physical or covalent crosslinks, leading to an elastic network retraction force that helps the hydrogel to attain an equilibrium swelling level. (TSIHLIS et al., 2010)

The additional swelling water imbibed after polar, hydrophobic and ionic groups become saturated with water is termed free water and fills the spaces between network chains and/or center of larger pores. As the network swells, depending on the degradability level, the gel will start to disintegrate and dissolve. (GARG et al., 2016)

Swelling is the property to absorb water and retain it for a relative long time. It can be estimated by different measurements methods, such as the Japanese Industrial Standard K8150, which immerses the dry hydrogel in deionized water for 48 hours at room temperature and then filters it using a stainless steel net, calculating the swelling as:

Swelling $=\frac{w_{s}-W_{d}}{w_{d}}$

Where $\mathrm{W}_{\mathrm{s}}$ indicates the hydrogel weight in swollen state, $\mathrm{W}_{\mathrm{d}}$ indicates the hydrogel weight in dry state. Similar measurements have been made under the terms "swelling ratio", "equilibrium degree of swelling" and "degree of swelling". (LIU et al., 2002, 2005; NAGASAWA et al., 2004; VALLÉS et al., 2000)

The swelling assessment can be a measure for many gel properties such as crosslinking degree, mechanical properties and degradation rate. This together with the swollen state stability are easy and cheap ways to differentiate crosslinking statuses and identify a crosslinked gel or a non-crosslinked original polymer. (GRIFFITH, 2000)

The exact swelling behavior is hard to be predicted due to highly non-ideal thermodynamic behavior of polymer networks in electrolyte solutions. Another theory used is the Flory-Rehner equation, which proposes swelling equilibrium when swelling force and retractive force induced by network crosslinks are equal. The chemical potential change of water at constant temperature and pressure can be calculated as:

$\mu_{1}-\mu_{1,0}=\Delta \mu_{\text {mix }}+\Delta \mu_{\text {elastic }}$

Where $\mu_{1}$ is the chemical potential of water in the system, $\mu_{1,0}$ is the chemical potential of pure swelling water, and $\Delta \mu_{\text {mix }}$ and $\Delta \mu_{\text {elastic }}$ are the mixing and elastic contributions to the total 
chemical potential change. The parameters $\Delta \mu_{\text {mix }}$ and $\Delta \mu_{\text {elastic }}$ can be determined by:

$\Delta \mu_{\text {mix }}=R \operatorname{Rln}\left(1-v_{2, s}\right)+v_{2, s}+\chi_{x g} v_{2, s}^{y}$

$\Delta \mu_{\text {elastic }}=\left(\frac{R T V_{1}}{\bar{v} M_{C}}\right)\left(\frac{1-2 M_{c}}{M_{n}}\right)\left(v_{2, s}^{1 / 3}-\frac{v_{2, s}}{2}\right)$

Where $\chi_{x g}$ is the biomedical polymer-water interaction parameter, $V_{1}$ is the water molar volume, $\bar{v}$ is the specific volume of the biomedical polymer, $v_{2, s}$ is the volume fraction of the swollen gel, $M_{c}$ is the average molecular weight between crosslinks and $M_{n}$ is the molecular weight of linear polymer chains without crosslinking. Both equations lead to the equation of the average molecular weight of biogels crosslinked in the presence of water:

$\frac{1}{M_{C}}=\frac{2}{\bar{M}_{n}}-\frac{\frac{\bar{v}}{V_{1}}\left[\ln \left(1-v_{2, s}\right)+v_{2, s}+\chi v_{2, s}^{2}\right]}{v_{2, r}\left[\left(\frac{v_{2, s}}{v_{2, r}}\right)^{1 / 3}-\frac{\varphi}{2}\left(\frac{v_{2, s}}{v_{2, r}}\right)\right]}$

Where $v_{2, r}$ is the polymer volume fraction in the relaxed state and $\varphi$ is the crosslinking agent functionality. In order to calculate $M_{c}$, the $v_{2, r}$ values can be evaluated experimentally as they are inversely related to the swelling ratio $\mathrm{Q}$, which depends on crosslinking degree and ionic strength of the medium according to Figure 5.

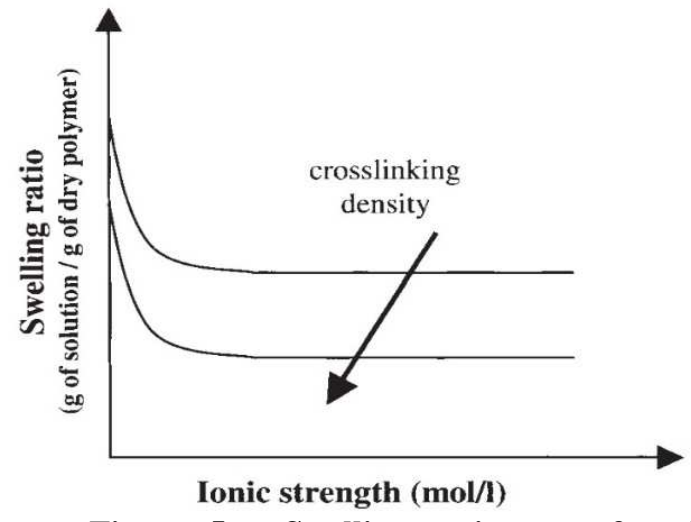

Figure 5 - Swelling ratio as a function of ionic strength and crosslinker concentration. (BORZACCHIELLO, 2009)

From the value of $M_{c}$ it is possible to estimate the endto-end distance of the solvent free (unperturbed) state:

$\left(r_{0}^{2}\right)^{1 / 2}=l\left(2 \frac{M_{c}}{M_{r}}\right)^{1 / 2} C_{n}^{1 / 2}$

Where $l$ is the bond length, $C_{n}$ is the polymer characteristic ratio and $M_{r}$ is the repeating unit molecular weight. From this, the mesh size can be calculated: (BORZACCHIELLO; AMBROSIO, [s.d.]; CANAL; PEPPAS, 1989)

$\xi=\left(r_{0}^{2}\right)^{1 / 2} v_{2, s}^{-1 / 3}$

\subsection{Porosity}

The average pore size, the pore size distribution and the pore interconnections are essential hydrogel factors that are often challenging to compute and are generally included in a parameter called tortuosity. Pore size distributions are influenced by three factors: i) concentration of chemical crosslinks of the polymer strands, calculated by the initial ratio of crosslinker to monomer; ii) concentration of physical entanglements of the polymer strands, determined by the initial concentration of all polymerizable monomers in the solution; and iii) net charge of the polyelectrolyte hydrogel, determined by the initial concentration of the cationic or anionic monomer. These three factors can be calculated by using the hydrogel composition:

$\% T=\frac{\text { monomer weight }+ \text { crosslinker weight }}{\text { total volume }}$

$\% C=\frac{\text { crosslinker weight }}{\text { monomer weight }+ \text { crosslinker weight }}$

The pore-size distribution depends on the hydrogel characterization expressed by equations 35 and 36 and influences the hydrogel design.

Porosity is a morphological characteristic and can be illustrated as the presence of void cavity inside the bulk. It is advantageous to control the porosity for a wide range of applications, such as optimizing cell migration in hydrogelbased scaffolds or tunable release of macromolecules. It can be calculated as:

Porosity $(\%)=\frac{V_{\text {pore }}}{V_{\text {bulk }}+V_{\text {pore }}} \times 100$

Porosity can be estimated by theoretic procedures, such as unit cube analysis, mass technique, Archimedes method, liquid displacement method, mercury porosimetry, gas adsorption, liquid extrusion porosity and various microscopy techniques engaged in both qualitative and quantitative tests. (GARG et al., 2016)

\subsection{Oscillatory Shearing Motion}

The rheological characterization of complex fluids is carried out using several controlled methods such as steady shear, stress relaxation, creep, oscillatory shear and steady extension. The results of each method are quantified using material functions such as steady viscosity, relaxation modulus, creep compliance storage and loss moduli, and extensional viscosity respectively. Oscillatory shear is widely used in characterizing viscoelastic materials, since relative contributions of viscous and elastic responses can be measured. (DESHPANDE et al., 2010)

Oscillatory shear can be divided based on amplitude; the nonlinearities existing in real experiments are either insignificant or too small to measure, which characterizes it as small amplitude oscillatory shear (SAOS), or they are significant, which characterizes large amplitude oscillatory shear (LAOS).

While SAOS studies have been widely common, LAOS studies have only become popularized in the past couple of decades with the development of more sensitive transducers in commercially available rheometers. It is used in order to obtain information regarding a material's nonlinear viscoelasticity and the way it changes in response to the deformations, involving both intercycle and intracycle measures. LAOS could help 
differentiate between suspensions of soft and rigid particles, which would look the same in SAOS experiments.

However, one of the major obstacles in LAOS studies is the lack of consensus in the approach used to obtain physical interpretations of the experimental data acquired. Many methods to improve data handling and processing were made using Fourier Transform and were called FT rheology, even though there remains no clear physical interpretation of the measured higher harmonics for an arbitrary material. (WILHELM, 2002) Other study proposed displaying the results as Lissajous figures, decomposing the stress into two constructions: elastic and viscous stresses. (CHO et al., 2005) Another study suggested using Chebyshev polynomials of the first kind to describe the elastic and viscous stresses, which was related to Fourier analysis. (EWOLDT et al., 2008) Still, the physical interpretations were shown to not be applied to all LAOS responses, which limited them even further. (ROGERS; LETTINGA, 2012) This lack of consensus and physical interpretations indicate a field still in development. (ROGERS, 2018)

For SAOS, there are two types of oscillatory shear tests: oscillatory frequency sweep and oscillatory amplitude sweet. In the frequency sweep test, the frequency is varied while the amplitude of the deformation, or the amplitude of the shear stress, is kept constant. In the amplitude sweep test, the angular frequency remains constant while the strain or stress amplitude increases as a function of the time. The strain and stress sweeps are defined as follows:

$\gamma(t)=\gamma_{0} \sin (\omega t)$

$\tau(t)=\tau_{0} \sin (\omega t)$

Where $\gamma$ is the strain and $\tau$ is the stress applied, the subscript " 0 " indicates the amplitude, $\omega$ is the angular frequency and $t$ indicates the time. The amplitude sweep test helps define the linear viscoelasticity range (LVE), the yield stress $\left(\tau_{y}\right)$ and the flow point $\left(\tau_{f}\right)$.

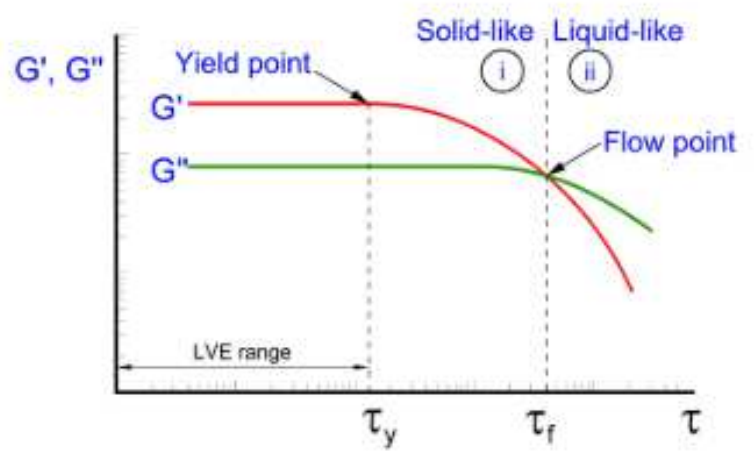

Figure 6 - Stress amplitude sweep plot illustrating linear viscoelasticity range $(\mathrm{LVE})$, the yield stress $\left(\tau_{y}\right)$ and the flow point $\left(\boldsymbol{\tau}_{f}\right)$. (SÁNCHEZ, 2018)

The storage modulus ( $\left.\mathrm{G}^{\prime}\right)$ and the loss modulus (G') exhibit a constant plateau within the LVE range, which is the region where the material can be tested without structure damage or changes. The limit value of the LVE range is defined as the yield stress.
The flow generated under shear conditions during SAOS testing is illustrated by Figures 7 and 8:

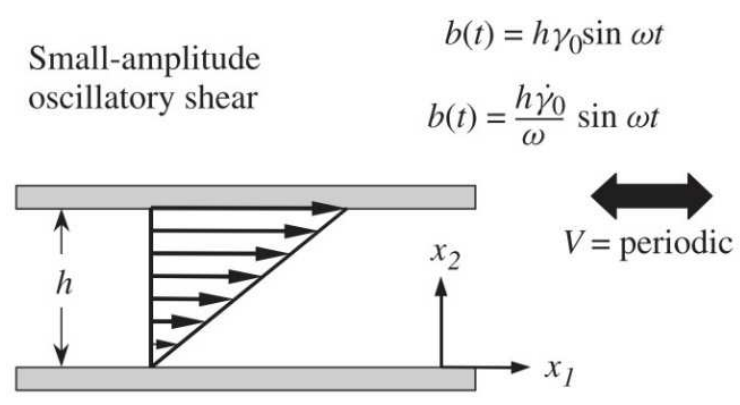

Figure 7 - Small amplitude oscillatory shear schematic. (MORRISON, 2001)

SAOS

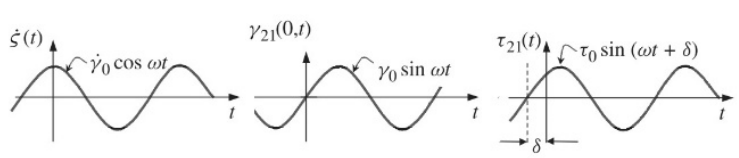

Figure 8 - Shear rate $(\dot{\boldsymbol{\zeta}})$, strain $\left(\gamma_{21}\right)$ and shear stress $\left(\tau_{21}\right)$ in SAOS functions. (MORRISON, 2001)

The shear rate is time-dependent and periodic. The kinematic is defined with the vector velocity as Equations 40 and 41:

$\underline{v}=\left(\begin{array}{c}\dot{\varsigma}(t) x_{2} \\ 0 \\ 0\end{array}\right)_{123}$

$\dot{\zeta}(t)=\dot{\gamma}_{0} \cos (\omega t)$

With $\dot{\zeta}(t)$ as the time-dependent shear-rate function, $\dot{\gamma}_{0}$ as the constant amplitude of the shear rate and $\omega$ the angular frequency. This flow is almost always carried out in a cone-andplate or parallel-plate rheometer. The wall motion required to produce SAOS can be calculated from the strain. Small shear strains can be written as Equation 42:

$\gamma_{21}=\frac{\Delta u_{1}}{\Delta x_{2}}$

The upper plate displacement for small strains $b(t)$ and the gap between the plates $h$ can be related to small strains as Equation 43:

$\gamma_{21}(0, t)=\frac{b(t)}{h}$

Using the function for general flow (steady or unsteady), it is possible to calculate the strain rate in Equations 44 and 45:

$\gamma_{21}(0, t)=\int_{0}^{t} \dot{\gamma}_{21}\left(t^{\prime}\right) d t^{\prime}=\frac{\dot{\gamma}_{0}}{\omega} \sin (\omega t)=\gamma_{0} \sin (\omega t)$

$b(t)=h \gamma_{0} \sin (\omega t)$

The strain amplitude is $\gamma_{0}=\dot{\gamma}_{0} / \omega$. At low strain amplitudes, the produced shear stress in a sample will be a sine wave with the same frequency as the input strain wave. However, the shear stress will usually be out of phase by $\delta$ with the input strain, thus written as Equation 47:

$-\tau_{21}(t)=\tau_{0} \sin (\omega t+\delta)$ 
$-\tau_{21}(t)=\tau_{0}(\sin \omega t \cos \delta+\sin \delta \cos \omega t)=$

$\left(\tau_{0} \cos \delta\right) \sin \omega t+\left(\tau_{0} \sin \delta\right) \cos \omega t$

The material functions for SAOS are defined based on the sinusoidal shear-stress output. Using trigonometric identities, it is possible to observe there is a portion of the stress wave in phase with the imposed strain (proportional to $\sin \omega t$ ) and a portion in phase with the imposed strain rate (proportional to $\cos \omega t)$. With Newtonian fluids, the shear-stress response is proportional to the imposed shear rate in Equation 48:

$\tau_{21}=-\mu \dot{\gamma}_{21}$

With elastic materials, the shear stress response is proportional to the imposed strain in Equation 49:

$\tau_{21}=-G \gamma_{21}$

Comparing the SAOS response to both Newtonian (viscous) and elastic materials, it is possible to observe that the response contains both a Newtonian-like part (proportional to $\dot{\gamma}_{21}$ ) and an elastic-like part (proportional to $\gamma_{21}$ ). Therefore, the SAOS experiment is ideal for viscoelastic materials - materials that show both viscous and elastic properties.

The material functions for SAOS are called storage modulus $G^{\prime}(\omega)$ and the loss modulus $G^{\prime \prime}(\omega)$, obtained through Equations 50, 51, 52 and 53:

$-\tau_{21}(t)=\left(\tau_{0} \cos \delta\right) \sin \omega t+\left(\tau_{0} \sin \delta\right) \cos \omega t$

$\frac{-\tau_{21}(t)}{\gamma_{0}}=G^{\prime}(\omega) \sin \omega t+G^{\prime \prime}(\omega) \cos \omega t$

$G^{\prime}(\omega)=\frac{\tau_{0}}{\gamma_{0}} \cos \delta$

$G^{\prime \prime}(\omega)=\frac{\tau_{0}}{\gamma_{0}} \sin \delta$

The measurement of the phase $\delta$ provides a method of quantifying the level of viscoelasticity of a material. As $\delta$ varies between zero and $\pi / 2$, small values of $\delta$ represent predominantly elastic behavior, while large values of $\delta$ represent predominantly viscous behavior. Another parameter related to the phase is the loss tangent, which indicates the ratio of viscous to elastic response calculated by Equation 54.

$\tan \delta=\frac{G \prime \prime}{G \prime}$

A tangent tending to infinity indicates a primarily elastic response, while a tangent tending to zero indicates a primarily viscous response. Other than storage and loss moduli, phase and tangent loss, SAOS tests are useful to determine other parameters, such as viscosity and compliance. (DESHPANDE et al., 2010; MORRISON, 2001)

\subsection{Viscosity}

Viscosity is the fluid resistance to flow upon application of stress, being generally determined by the polymer concentration and molecular weight. It can be measured by viscometers and rheometers, with the latter possessing a wider measurement range and being capable of measuring other properties as well. It directly influences shape fidelity after deposition, which increases with increasing viscosity, cell viability, which can negatively affect cells with the increase of the applied shear stress, and surface tension-driven droplet formation, which is prevented with viscosity increase. (AGUADO et al., 2012; MALDA et al., 2013; SCHUURMAN et al., 2013)

While cell viability is affected by viscosity in extrusionbased bioprinting, increasing the bioink viscosity in laserassisted bioprinting improves viability, since it reduces jet velocity and minimizes impact during printing. (CATROS et al., 2011) In droplet-based bioprinting, higher viscosity prevents droplet ejection and lower viscosity produces unwanted satellite droplets. (DERBY, 2010)

In order to predict printability, viscosity has been defined in terms of loss and storage moduli in Equation 55: (GAO et al., 2018)

$\eta=\frac{\left({G^{\prime}}^{2}+G^{\prime \prime 2}\right)^{1 / 2}}{y^{\prime}}$

During oscillatory shearing tests, the frequencydependent viscosity, also called complex viscosity $\eta^{*}$, is defined by Equations 56 and 57:

$\eta^{*}=\eta^{\prime}+i \eta^{\prime \prime}$

$\left\|\eta^{*}\right\|=\sqrt{\eta^{\prime 2}+\eta^{\prime \prime 2}}$

Where $\eta^{\prime}$ is the real part of the complex viscosity, also known as dynamic viscosity and related to the loss modulus in Equation 58, and $\eta^{\prime \prime}$ is the imaginary part of the complex viscosity, also known as out-of-phase viscosity and related to the storage modulus in Equation 59.

$\eta^{\prime}=\frac{G^{\prime}}{\omega}$
$\eta^{\prime \prime}=\frac{G^{\prime \prime}}{\omega}$

As hydrogels are usually non-Newtonian fluids, their viscosity is not a fixed value and varies according to shear rate variation. Due to its dependency on shear rate, the measured viscosity for non-Newtonian fluids is called the "apparent viscosity". According to the viscosity changes in response to shear rate changes, several types of non-Newtonian behaviors are possible, as indicated in Figure 9.

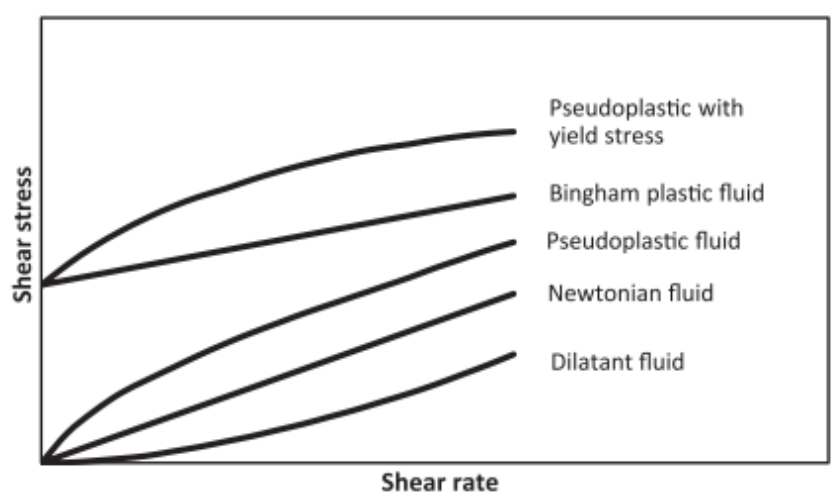

Figure 9 - Flow curves for Newtonian and non-Newtonian fluids. (KULKARNI; SHAW, 2016)

The properties associated with material recovery time are referred to as thixotropy, where the apparent viscosity decreases with time when the material is exposed to conditions of constant shear rate, and rheopexy, where the apparent viscosity increases with time when the material is exposed to constant shear rate conditions, shown in Figure 10. 

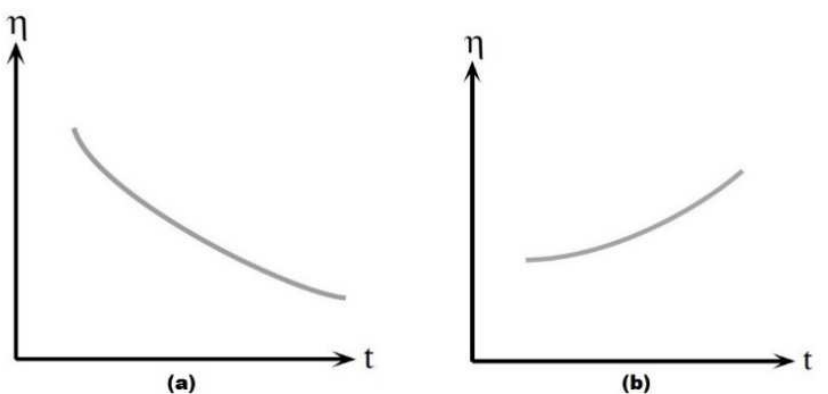

Figure 10 - Time-dependent viscosity indicating (a) thixotropic behavior and (b) rheopectic behavior. (KAZEMIAN et al., 2010)

Plastic behavior is characterized by a fluid requiring a certain amount of force applied to it in order to induce flow. This force is called "yield stress", as shown in Figure 11. Once this value is exceeded, flow begins and the fluid may display Newtonian, pseudoplastic or dilatant flow characteristics. (STRUBLE; JI, 2002)

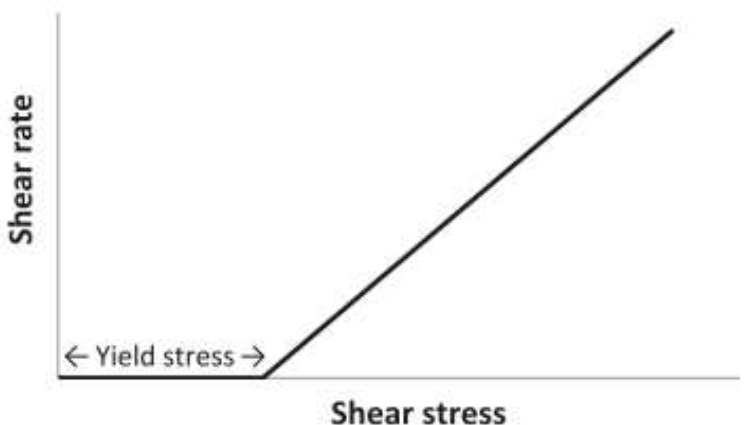

Figure 11 - Flow curve for plastic behavior. (KULKARNI; SHAW, 2016)

Dilatant or shear thickening behavior as shown in Figure 12 is characterized by an increase in viscosity with the increase in shear rate. It is less common than shear thinning, being frequently seen in fluids with high levels of deflocculated solids (corn starch/water mixtures, sand/water mixtures, clay slurries). (MORRISON, 2001; TOWNSEND et al., 2019)

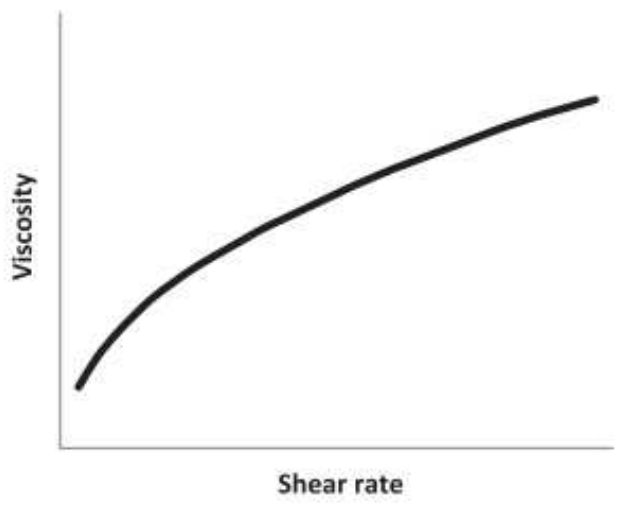

Figure 12 - Shear thickening or dilatant behavior (KULKARNI; SHAW, 2016)

Pseudoplastic or shear-thinning behavior as shown in Figure 13 is characterized by a decrease in viscosity with the increase in shear rate. It is the most common non-Newtonian behavior, with shear-thinning fluids exhibiting good suspension stability or drip resistance when at rest and thinning down while being "worked" on. It commonly occurs in polymer melts, concentrated polymer solutions and in colloidal dispersions. Measuring viscosity at a single shear rate does not indicate the full behavior picture, so a flow curve across a range of shear rates will enable a better study and evaluation of process conditions. (MORRISON, 2001; TOWNSEND et al., 2019)

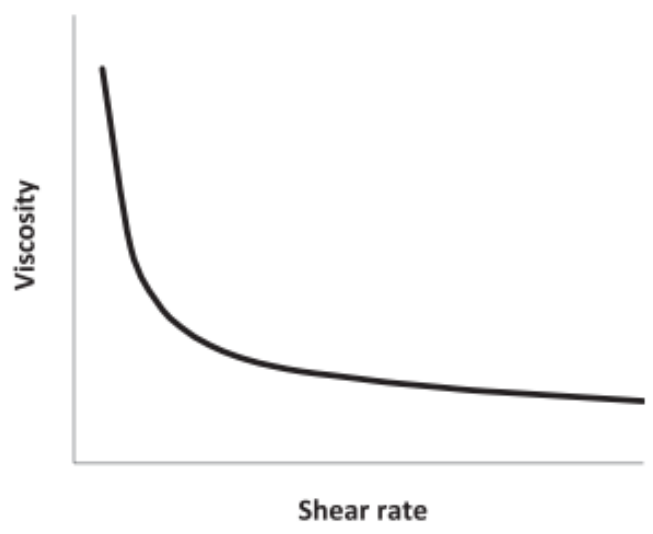

Figure 13 - Shear thinning behavior. (KULKARNI; SHAW, 2016)

A plot of $\log$ viscosity vs $\log$ shear rate represents most non-Newtonian, shear thinning materials. At low shear rates the entangled molecules have a hard time sliding past each other, presenting a constant viscosity region known as the "first Newtonian plateau" or "zero-shear viscosity" $\left(\eta_{0}\right)$. As the shear rate increases, the shearing action disentangles and unravels the molecules, with the disentangled molecules sliding past their neighbors more easily and leading to a sharp decrease in viscosity, known as the Power Law region. When the molecules can't stretch any further, a constant viscosity region is presented, known as the "second Newtonian plateau" or "infinite-shear viscosity" $\left(\eta_{\infty}\right)$. The plot is shown in Figure 14 to better visualize both Newtonian plateaus and the Power Law Region. (KULKARNI; SHAW, 2016; OSSWALD; RUDOLPH, 2015a)

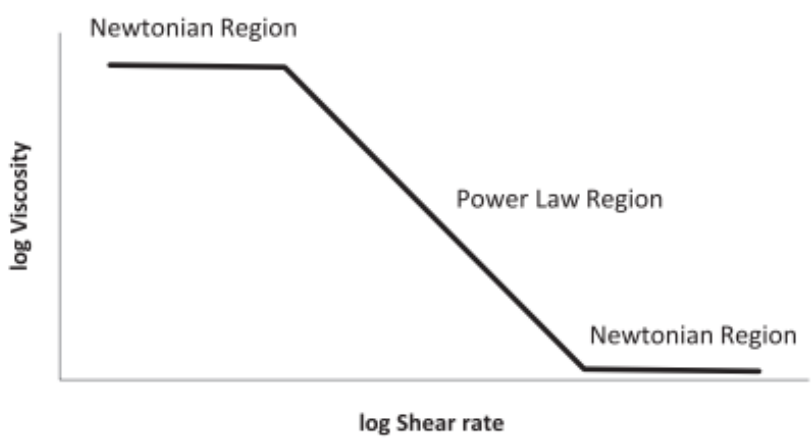

Figure 14 - Log-log plot of shear thinning behavior. (KULKARNI; SHAW, 2016)

Several mathematical models are used to analyze the obtained data and help characterize the fluid behavior. Different flow behavior requires different models to better fit the viscosity data. A simple model used is the Power Law model proposed by Ostwald and de Waele. It is used to describe the shear thinning or shear thickening behavior in materials and neglects yield 
response and the Newtonian plateau at small strain rates. The model can be written as:

$\eta=m \dot{\gamma}^{n-1}$

Where $\eta$ is the viscosity, $m$ is referred to as the consistency index, $\dot{\gamma}$ is the shear rate and $n$ is the Power Law or flow index. Both Power Law and consistency indexes are known for common materials. The index $n$ represents different behaviors according to its value: $n=1$ represents Newtonian behavior, $n<1$ represents shear thinning behavior and $n>1$ represents shear thickening behavior. (HACKLEY; FERRARIS 2001; KULKARNI; SHAW, 2016; OSSWALD; RUDOLPH, 2015a)

The Power Law model has been used due to its simple formula expressing the relation between shear stress and shear rate. Its major drawback is its accuracy, which is heavily dependent on shear rate range: most commercial rheological configurations provide data for a limited shear rate range, making obtaining flow information at both low $\left(<1 \mathrm{~s}^{-1}\right)$ and high $\left(>1000 \mathrm{~s}^{-1}\right)$ shear rates a challenging situation. A plot of $\log$ viscosity vs log shear rate in Figure 15 helps visualize the accuracy issue between the Power Law model approximation and the viscosity curve. (OSSWALD; RUDOLPH, 2015b)

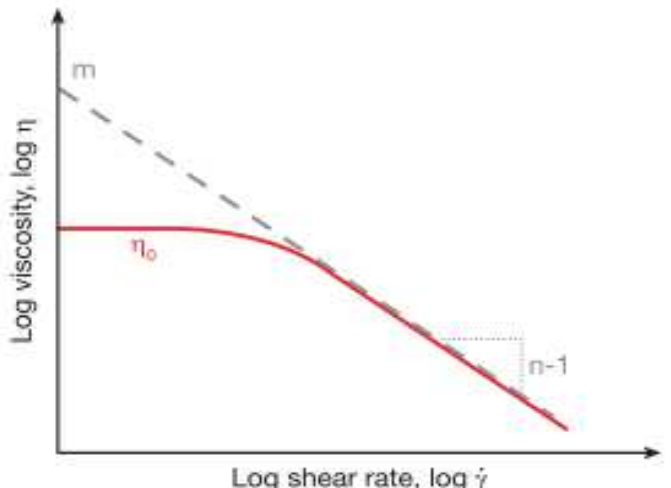

Figure 15 - Viscosity curve (solid) and Power Law model approximation (dashed) with Power Law and consistency indexes. (OSSWALD; RUDOLPH, 2015b)

The Cross-WLF model considers the effects of shear rate and temperature on the viscosity, describing both Newtonian and shear thinning behavior within a wider range of shear rates compared to the Power Law model. It is the most common model used by injection molding softwares, offering the best fit to viscosity data. (HACKLEY; FERRARIS, 2001; HIEBER; CHIANG, 1992) The shear thinning part is modeled by:

$$
\frac{\eta-\eta_{\infty}}{\eta_{0}-\eta_{\infty}}=\frac{1}{1+(\lambda \dot{\gamma})^{1-n}}
$$

Where $\lambda$ is a time constant. For $\eta \gg \eta_{\infty}$ and $\eta \ll \eta_{0}$, the Cross model is reduced to the Power Law model. If the infiniteshear viscosity is negligible, the Cross-WLF model can be written as:

$$
\eta(\dot{\gamma})=\frac{\eta_{0}}{1+\left(\frac{\eta_{0} \dot{\gamma}}{\tau^{*}}\right)^{1-n}}
$$

The Herschel-Bulkley model is widely used to represent the behavior of viscoplastic materials exhibiting a yield response and a Power Law relationship between shear stress and shear rate above the yield stress. It is basically a Power Law model with a yield stress term:

$$
\begin{array}{ll}
\tau=\tau_{0}+m \dot{\gamma}^{n} & \\
\eta=\frac{\tau_{0}}{\dot{\gamma}}+m \dot{\gamma}^{n-1} & \tau>\tau_{0}
\end{array}
$$

Below the required critical stress $\tau_{0}$, the material sustains stress without flow, but above it, the material flows like a Power Law fluid. As with the Power Law model, $n<1$ represents shear thinning behavior, $n>1$ represents shear thickening behavior and $n=1$ reduces the model to the Bingham model representing Newtonian flor above the critical yield stress.

Figure 16 shows that all models discussed can be derived from one base equation with different assumptions for behavior. The Power Law model, while the simplest, can be used when there is high shear rate. The Cross-WLF model is the most common in numerical simulations, fitting the viscosity data of a wide range of materials. The Herschel-Bulkley model links both the Power Law and Bingham models. (HACKLEY; FERRARIS, 2001; OSSWALD; RUDOLPH, 2015a)

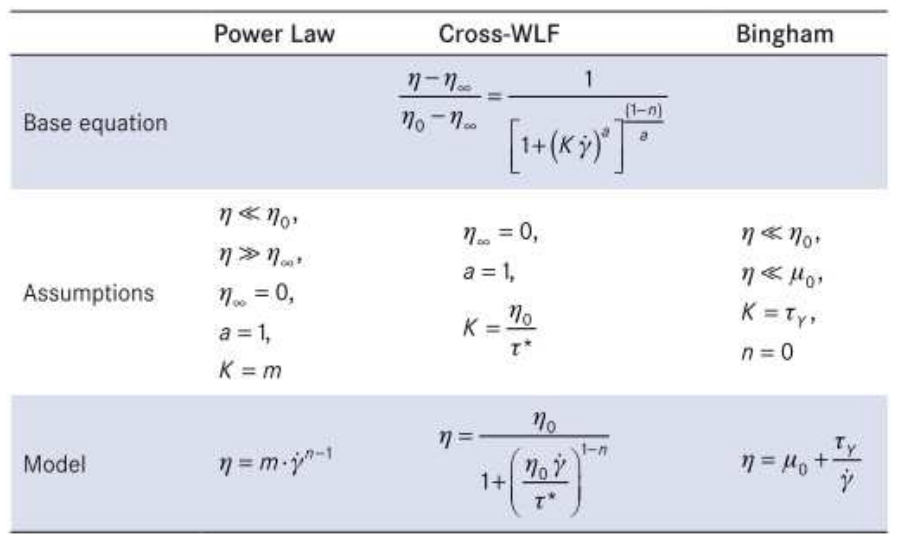

Figure 16 - Expressions describing steady shear nonNewtonian flow. (OSSWALD; RUDOLPH, 2015a)

\section{CHALLENGES AND FUTURE TRENDS}

Bioprinting is a promising solution for the globally increasing organ shortage for transplantation, as well as for pharmaceutical tests in animals and its subsequent ethical discussions. In order to further advance the field to reach a complete and functional printing of complex tissues and organs, some challenges must be surpassed which generally fall into one of three categories: technical, commercial or ethical challenges.

Technical challenges involve in vivo integration and printability challenges. The latter involves development of bioinks and bioprinting methods in order to obtain higher resolution during and after printing. MIN et al. (MIN et al., 2017) have developed a 3D bioprinting procedure capable of producing skin tissue with pigmentations, while KIM et al. (KIM et al., 2017) invented a procedure using extrusion and inkjet modules simultaneously for human skin engineering possessing 50 times a lower cost and 10 times less medium consumption when compared to a stereotyped culture. GUO et al. (GUO et al., 2017) have developed a multifunctional bioprinting method for stretchable tactile sensors fabrication with capability of detecting and differentiating human movements. 
Bioink development has been made aiming to improve printing resolution, structural and biological performance. A special bioink was developed to provide conductivity and avoid delayed electrical coupling in cardiac cells and was shown to be printable, cytocompatible and to enhance functionality in cardiac cells. (ZHU et al., 2017) Bioinks have been studied for vascularized bioprinted tissues (KOLESKY et al., 2014, 2016), with strain sensors within structures guiding the self-assembly of cardiac tissue (LIND et al., 2017), and with self-healing hydrogels used along with shear-thinning hydrogels providing support for direct printing of 3D constructs (HIGHLEY et al., 2015). Another bioink development has been the mixture between natural and synthetic materials, providing semisynthetic hydrogels in order to combine biocompatibility and mechanical stability. (BEHESHTIZADEH et al., 2020; RUTZ et al., 2015)

In vivo integration is a significant challenge in tissue and organ engineering. Without proper vascularization, interior cells do not receive adequate nutrition, growth factors and oxygen, leading to cell death, necrotic tissues, loss of graft function and infection (BEHESHTIZADEH et al., 2020). The study of ECMs and their composition, distribution and function has led to the suggestion of artificial vascular systems and fluidic channels. (DERAKHSHANFAR et al., 2018; KAULLY et al., 2009)

Bioprinting's potential implementations makes it a promising market estimated to obtain a $\$ 10.8$ billion worth in 2021 (ARSLAN-YILDIZ et al., 2016), however it still presents considerable commercial challenges involving the bioprinting process' optimization, which is not currently automated and entails manual operations separated in various steps, resulting in slow processing speed and increasing the possibility of errors (MANDRYCKY et al., 2016). Besides scalable manufacturing, other challenges are present like regulatory approval, insurance, hospital and medical policies and logistics (JAKUS et al., 2016).

Ethical challenges include the necessity of a new regulatory framework for clinical evaluation. Due to each patient's unique genetic makeup, the standardization and personalized medical treatments must be regulated and developed for 3D bioprinting. Regulatory agencies worldwide have found this field challenging since it is a subcategory of $3 \mathrm{D}$ printing but does not follow the same regulation rationale due to the different policy consideration from the perspective of human health and safety. There may be questionable biomaterial sources, unhealthy donors, post-transplant issues, patient's medical access, animal testing issues among other concerns (LI, 2018). Only South Korea and Japan have provided some kind of regulatory guidance applicable do 3D bioprinting, however the guidance is broad and loosely applicable (LETOURNEAU et al., 2015).

Considering the challenges currently being addressed, 3D bioprinting has created an impact in the tissue analysis field and is being used as a practical tool do produce human body tissues, specifically bone, cartilage, skin, nerve and kidney tissues (BEHESHTIZADEH et al., 2020; DALY et al., 2018; DERAKHSHANFAR et al., 2018; HERNÁNDEZGONZÁLEZ; TÉLLEZ-JURADO; RODRÍGUEZ-LORENZO, 2020; HOMAN et al., 2016; HUANG; BÁRTOLO, 2018; JOHNSON et al., 2015; KEBEDE et al., 2018; KESTI et al., 2015). It is predicted that $3 \mathrm{D}$ bioprinting methods will lead to in situ bioprinting development and to the development of preclinical tumor models in the form of 3D in vitro cancer models for further studying. (ALBANNA et al., 2019; SINGH et al., 2020)

Another promising trend involves the use of smart materials - time-dependent, stimuli-responsive, self-evolving materials which are dynamic upon contact with external stimuli such as $\mathrm{pH}$, temperature, electricity, etc. This technology, initiated and termed in 2013, is known as 4D printing and is reported as the most significant transformation in existing $3 \mathrm{D}$ printing and traditional manufacturability. It can be used to print heart valves designed as per patient requirement based on data acquired from CT and MRI, skin, liver and kidney implants. (HALEEM; JAVAID, 2018; ZAFAR; ZHAO, 2020) Although tissue printing is still in its earlier stages, $4 \mathrm{D}$ bioprinting is a promising field that can resolve many of the challenges currently present in organ printing. The study and development of new materials, new bioinks and new bioprinting methods are crucial to achieve a fully functional printed human organ and a solution to organ shortage for transplantation.

\section{R E F E R E N C E S}

ABELARDO, E. Synthetic material bioinks. In: 3D Bioprinting for Reconstructive Surgery: Techniques and Applications. [s.l: s.n.]. DOI: 10.1016/B978-0-08-1011034.00009-0.

AGUADO, Brian A.; MULYASASMITA, Widya; SU, James; LAMPE, Kyle J.; HEILSHORN, Sarah C. Improving viability of stem cells during syringe needle flow through the design of hydrogel cell carriers. Tissue Engineering - Part A, [S. l.], v. 18, n. 7-8, p. 806-815, 2012. DOI: 10.1089/ten.tea.2011.0391. AHMED, Tamer A. E.; DARE, Emma V.; HINCKE, Max; AL, Et. Fibrin: A versatile scaffold for tissue engineering applications. Tissue Engineering - Part B: Reviews, [S. l.], v. 14, n. 2, p. 199-215, 2008. DOI: 10.1089/ten.teb.2007.0435. ALBANNA, Mohammed et al. In Situ Bioprinting of Autologous Skin Cells Accelerates Wound Healing of Extensive Excisional Full-Thickness Wounds. Scientific

Reports, [S. l.], v. 9, n. 1, p. 1-15, 2019. DOI: 10.1038/s41598-018-38366-w. Disponível em: http://dx.doi.org/10.1038/s41598-018-38366-w.

ALLISON, David D.; GRANDE-ALLEN, K. Jane. Review. Hyaluronan: A powerful tissue engineering tool. Tissue Engineering, [S. l.], v. 12, n. 8, p. 2131-2140, 2006. DOI: 10.1089/ten.2006.12.2131.

ARSLAN-YILDIZ, Ahu; EL ASSAL, Rami; CHEN, Pu; GUVEN, Sinan; INCI, Fatih; DEMIRCI, Utkan. Towards artificial tissue models: Past, present, and future of 3D bioprinting. Biofabrication, [S. l.], v. 8, n. 1, p. 1-17, 2016. ATHAWALE, V. D.; LELE, Vidyagauri. Graft copolymerization onto starch. II. Grafting of acrylic acid and preparation of it's hydrogels. Carbohydrate Polymers, [S. l.], v. 35, n. 1-2, p. 21-27, 1998. DOI: 10.1016/S01448617(97)00138-0.

BEHESHTIZADEH, Nima; LOTFIBAKHSHAIESH, Nasrin; PAZHOUHNIA, Zahra; HOSEINPOUR, Mahdieh; NAFARI, Masoud. A review of 3D bio-printing for bone and skin tissue engineering: a commercial approach. Journal of Materials Science, [S. l.], v. 55, n. 9, p. 3729-3749, 2020. DOI: 
10.1007/s10853-019-04259-0.

Disponível

https://doi.org/10.1007/s10853-019-04259-0.

BENTON, Gabriel; KLEINMAN, Hynda K.; GEORGE, Jay; ARNAOUTOVA, Irina. Multiple uses of basement membranelike matrix (BME/Matrigel) in vitro and in vivo with cancer cells. International Journal of Cancer, [S. l.], v. 128, n. 8, p. 1751-1757, 2011. DOI: 10.1002/ijc.25781.

BERTASSONI, Luiz E. et al. Direct-write bioprinting of cellladen methacrylated gelatin hydrogels. Biofabrication, [S. l.], v. 6, n. 2, 2014. DOI: 10.1088/1758-5082/6/2/024105.

BORZACCHIELLO, Assunta; Structure-Property Relationships in Hydrogels. In: Hydrogels: Biological Properties and Applications. 1. ed. Milan, ITA: Springer, 2009.

BORZACCHIELLO, Assunta; AMBROSIO, Luigi. StructureProperty Relationships in Hydrogels 1 Hydrogel classification and basic structure. [S. l.], [s.d.].

CAMCI-UNAL, Gulden; CUTTICA, Davide; ANNABI, Nasim; DEMARCHI, Danilo; KHADEMHOSSEINI, Ali. Synthesis and characterization of hybrid hyaluronic acid-gelatin hydrogels. Biomacromolecules, [S. l.], v. 14, n. 4, p. 1085 1092, 2013. DOI: 10.1021/bm3019856.

CANAL, Tiziana; PEPPAS, Nikolaos A. Correlation between mesh size and equilibrium degree of swelling of polymeric networks. Journal of Biomedical Materials Research, [S. l.], v. 23, n. 10, p. 1183-1193, 1989. DOI: 10.1002/jbm.820231007. CATROS, Sylvain; GUILLOTIN, Bertrand; BAČÁKOVÁ, Markéta; FRICAIN, Jean Christophe; GUILLEMOT, Fabien. Effect of laser energy, substrate film thickness and bioink viscosity on viability of endothelial cells printed by laserassisted bioprinting. Applied Surface Science, [S. l.], v. 257, n. 12, p. 5142-5147, 2011. DOI: 10.1016/j.apsusc.2010.11.049.

CHO, Kwang Soo; HYUN, Kyu; AHN, Kyung Hyun; LEE, Seung Jong. A geometrical interpretation of large amplitude oscillatory shear response. Journal of Rheology, [S. l.], v. 49, n. 3, p. 747-758, 2005. DOI: 10.1122/1.1895801.

CUI, Xiaofeng; BREITENKAMP, Kurt; FINN, M. G.; LOTZ, Martin; D'LIMA, Darryl D. Direct human cartilage repair using three-dimensional bioprinting technology. Tissue Engineering - Part A, [S. l.], v. 18, n. 11-12, p. 1304-1312, 2012. DOI: 10.1089/ten.tea.2011.0543.

DALY, Andrew C.; PITACCO, Pierluca; NULTY, Jessica; CUNNIFFE, Gráinne M.; KELLY, Daniel J. 3D printed microchannel networks to direct vascularisation during endochondral bone repair. Biomaterials, [S. l.], v. 162, p. 3446, 2018.

DEITCH, Sandra; KUNKLE, Catherine; CUI, Xiaofeng; BOLAND, Thomas; DEAN, Delphine. Collagen matrix alignment using inkjet printer technology. Materials Research Society Symposium Proceedings, [S. l.], v. 1094, p. 52-57, 2008. DOI: 10.1557/proc-1094-dd07-16.

DERAKHSHANFAR, Soroosh; MBELECK, Rene; XU, Kaige; ZHANG, Xingying; ZHONG, Wen; XING, Malcolm. 3D bioprinting for biomedical devices and tissue engineering: A review of recent trends and advances. Bioactive Materials, [S. l.], v. 3, n. 2, p. 144-156, 2018. DOI: 10.1016/j.bioactmat.2017.11.008. Disponível em: https://doi.org/10.1016/j.bioactmat.2017.11.008.

DERBY, Brian. Bioprinting: Inkjet printing proteins and hybrid cell-containing materials and structures. Journal of Materials Chemistry, [S. l.], v. 18, n. 47, p. 5717-5721, 2008. DOI: 10.1039/b807560c.

DERBY, Brian. Inkjet Printing of Functional and Structural
Materials: Fluid Property Requirements, Feature Stability, and Resolution. Annual Review of Materials Research, [S. l.], v. 40 , n. 1 , p. $395-414,2010$. DOI: $10.1146 /$ annurev-matsci070909-104502.

DES RIEUX, Anne; SHIKANOV, Ariella; SHEA, Lonnie D.; AL, Et. Fibrin hydrogels for non-viral vector delivery in vitro. Journal of Controlled Release, [S. l.], v. 136, n. 2, p. 148-154, 2009. DOI: 10.1016/j.jconrel.2009.02.004. Disponível em: http://dx.doi.org/10.1016/j.jconrel.2009.02.004.

DESHPANDE, Abhijit P.; KRISHNAN, J. Murali; KUMAR, P. B. Suni.; AL, Et. Rheology of complex fluids. [s.l: s.n.]. DOI: 10.1007/978-1-4419-6494-6.

DIKOVSKY, Daniel; BIANCO-PELED, Havazelet; SELIKTAR, Dror; AL, Et. The effect of structural alterations of PEG-fibrinogen hydrogel scaffolds on 3-D cellular morphology and cellular migration. Biomaterials, [S. l.], v. 27, n. 8, p. 14961506, 2006. DOI: 10.1016/j.biomaterials.2005.09.038.

EWOLDT, Randy H.; HOSOI, A. E.; MCKINLEY, Gareth H.; AL, Et. An ontology for large amplitude oscillatory shear flow. AIP Conference Proceedings, [S. l.], v. 1027, n. 2008, p. 11351137, 2008. DOI: 10.1063/1.2964492.

EYRICH, Daniela; BRANDL, Ferdinand; APPEL, Bernhard; WIESE, Hinrich; MAIER, Gerhard; WENZEL, Magdalene; STAUDENMAIER, Rainer; GOEPFERICH, Achim; BLUNK, Torsten. Long-term stable fibrin gels for cartilage engineering. Biomaterials, $[S$. l.], v. 28, n. 1, p. 55-65, 2007. DOI: 10.1016/j.biomaterials.2006.08.027.

FAKHARI, A.; BERKLAND, C. Applications and emerging trends of hyaluronic acid in tissue engineering, as a dermal filler and in osteoarthritis treatment. Acta Biomaterialia, [S. l.], v. 9, n. 7, p. 7081-7092, 2013. DOI: 10.1016/j.actbio.2013.03.005. Disponível em: http://dx.doi.org/10.1016/j.actbio.2013.03.005. FEDOROVICH, Natalja E.; DE WIJN, Joost R.; VERBOUT, Abraham J.; ALBLAS, Jacqueline; DHERT, Wouter J. A. Three-dimensional fiber deposition of cell-laden, viable, patterned constructs for bone tissue printing. Tissue Engineering - Part A., [S. l.], v. 14, n. 1, p. 127-133, 2008. DOI: 10.1089/ten.a.2007.0158.

FERREIRA, Ana Marina; GENTILE, Piergiorgio; CHIONO, Valeria; CIARDELLI, Gianluca. Collagen for bone tissue regeneration. Acta Biomaterialia, [S. l.], v. 8, n. 9, p. 31913200, 2012. DOI: 10.1016/j.actbio.2012.06.014. Disponível em: http://dx.doi.org/10.1016/j.actbio.2012.06.014.

FOOX, Maytal;; ZILBERMAN, Meital. Drug delivery from gelatin-based systems. Expert Opinion on Drug Delivery, [S. l.], v. $12, \quad$ n. 9 , p. 1547-1563, 2015. DOI: 10.1517/17425247.2015.1037272.

FRISCH, Steven M.; FRANCIS, Hunter. Disruption of epithelial cell-matrix interactions induces apoptosis. Journal of Cell Biology, [S. l.], v. 124, n. 4, p. 619-626, 1994. DOI: 10.1083/jcb.124.4.619.

GALLER, Kerstin M.; CAVENDER, Adriana C.; KOEKLUE, Umut; SUGGS, Laura J.; SCHMALZ, Gottfried; D'SOUZA, Rena N. Bioengineering of dental stem cells in a PEGylated fibrin gel. Regenerative Medicine, [S. l.], v. 6, n. 2, p. 191200, 2011. DOI: 10.2217/rme.11.3.

GAO, Guifang; YONEZAWA, Tomo; HUBBELL, Karen; DAI, Guohao; CUI, Xiaofeng. Injket-bioprinted acrylated peptides and PEG hydrogel with human mesenchymal stem cells promote robust bone and cartilage formation with minimal printhead clogging. Biotechnology Journal, [S. l.], v. 10, n. 10, p. 156877, 2015. DOI: 10.1017/CBO9781107415324.004.

GAO, Teng; GILLISPIE, Gregory J.; COPUS, Joshua S.; 
KUMAR PALLICKAVEEDU RAJAN ASARI, Anil; SEOUL, Young-Joon; ATALA, Anthony; YOO, J. J.; LEE, Sang Jin; AL, Et. Optimization of gelatin-alginate composite bioink printability using rheological parameters: a systematic approach. Biofabrication, [S. l.], v. 10, n. 3, p. 1-46, 2018.

GARG, Sweta; GARG, Ashish; VISHWAVIDYALAYA, Rani Durgavati; AL, Et. Hydrogel: Classification , Properties , Preparation and Technical Features. Asian Journal of Biomaterial Research, [S. l.], v. 2, n. 6, p. 163-170, 2016. Disponível em: https://www.researchgate.net/publication/316075989\%0AHydr ogel:

GOPINATHAN, Janarthanan; NOH, Insup. Recent trends in bioinks for 3D printing. Biomaterials Research, [S. l.], v. 22, n. 1, p. 1-15, 2018. DOI: 10.1186/s40824-018-0122-1.

GRIFFITH, L. G. Polymeric biomaterials. Acta Materialia, [S. l.], v. 48, n. 1, p. 263-277, 2000. DOI: 10.1007/978-0-38784872-3_3.

GROLL, J. et al. A definition of bioinks and their distinction from biomaterial inks. Biofabrication, [S. l.], v. 11, n. 1, 2019. DOI: 10.1088/1758-5090/aaec52.

GUO, Shuang Zhuang; QIU, Kaiyan; MENG, Fanben; PARK, Sung Hyun; MCALPINE, Michael C. 3D Printed Stretchable Tactile Sensors. Advanced Materials, [S. l.], v. 29, n. 27, p. 18, 2017. DOI: 10.1002/adma.201701218.

HACKLEY, Vincent A.; FERRARIS, Chiara F. Guide to Rheological Nomenclature. [s.l: s.n.].

HALEEM, Abid; JAVAID, Mohd. 4D printing applications in cardiology. Current Medicine Research and Practice, [S. l.], v. 8, n. 6, p. 245, 2018. DOI: 10.1016/j.cmrp.2018.10.001. Disponível em: https://doi.org/10.1016/j.cmrp.2018.10.001.

HASSAN, C. M.; PEPPAS, N. A. Structure and applications of poly(vinyl alcohol) hydrogels produced by conventional crosslinking or by freezing/thawing methods. In: Biopolymers - PVA Hydrogels, Anionic Polymerisation Nanocomposites. [s.1: s.n.]. v. 153p. 37-65. DOI: 10.1007/3-540-46414-X_2.

HE, Yong; YANG, Feifei; ZHAO, Haiming; GAO, Qing; XIA, Bing; FU, Jianzhong. Research on the printability of hydrogels in 3D bioprinting. Scientific Reports, [S. l.], v. 6, p. 1-13, 2016. DOI: $10.1038 /$ srep29977. Disponível em: http://dx.doi.org/10.1038/srep29977.

HEMSHEKHAR, Mahadevappa; THUSHARA, Ram M.; CHANDRANAYAKA, Siddaiah; SHERMAN, Larry S.; KEMPARAJU, Kempaiah; GIRISH, Kesturu S. Emerging roles of hyaluronic acid bioscaffolds in tissue engineering and regenerative medicine. [s.1.] : Elsevier B.V., 2016. v. 86 DOI: 10.1016/j.ijbiomac.2016.02.032. Disponível em: http://dx.doi.org/10.1016/j.ijbiomac.2016.02.032.

HENNINK, Wim E.; VAN NOSTRUM, C. F. Novel crosslinking methods to design hydrogels. Journal of Molecular Biology, [S. l.], v. 54, p. 13-36, 2002. DOI: 10.1016/0022-2836(75)90369-1.

HERN, Diane L.; HUBBELL, Jeffrey A. Incorporation of adhesion peptides into nonadhesive hydrogels useful for tissue resurfacing. Journal of Biomedical Materials Research, [S. l.], n. 39, p. 266-276, 1998.

HERNÁNDEZ-GONZÁLEZ, Aurora C.; TÉLLEZ-JURADO, Lucía; RODRÍGUEZ-LORENZO, Luis M. Alginate hydrogels for bone tissue engineering, from injectables to bioprinting: A review. Carbohydrate Polymers, [S. l.], v. 229, 2020. DOI: 10.1016/j.carbpol.2019.115514.

HIEBER, C. A.; CHIANG, H. H. Shear-rate-dependence modeling of polymer melt viscosity. Polymer Engineering \&
Science, $[S$. l.], v. 32, n. 14, p. 931-938, 1992. DOI: 10.1002/pen.760321404.

HIGHLEY, Christopher B.; RODELL, Christopher B.; BURDICK, Jason A.; AL, Et. Direct 3D Printing of ShearThinning Hydrogels into Self-Healing Hydrogels. Advanced Materials, [S. l.], v. 27, n. 34, p. 5075-5079, 2015. DOI: 10.1002/adma.201501234.

HOCKADAY, L. A. et al. Rapid 3D printing of anatomically accurate and mechanically heterogeneous aortic valve hydrogel scaffolds. Biofabrication, [S. l.], v. 4, n. 3, 2012. DOI: 10.1088/1758-5082/4/3/035005.

HOMAN, Kimberly A.; KOLESKY, David B.; SKYLARSCOTT, Mark A.; HERRMANN, Jessica; OBUOBI, Humphrey; MOISAN, Annie; LEWIS, Jennifer A. Bioprinting of 3D Convoluted Renal Proximal Tubules on Perfusable Chips. Scientific Reports, [S. l.], v. 6, p. 1-13, 2016. DOI: 10.1038/srep34845. http://dx.doi.org/10.1038/srep34845.

HONG, Sungmin; SYCKS, Dalton; CHAN, Hon Fai; LIN, Shaoting; LOPEZ, Gabriel P.; GUILAK, Farshid; LEONG, Kam W.; ZHAO, Xuanhe. 3D Printing of Highly Stretchable and Tough Hydrogels into Complex, Cellularized Structures. Advanced Materials, [S. l.], v. 27, n. 27, p. 4035-4040, 2015. DOI: 10.1002/adma.201501099.

HOSPODIUK, Monika; DEY, Madhuri; SOSNOSKI, Donna; OZBOLAT, Ibrahim T. The bioink: A comprehensive review on bioprintable materials. Biotechnology Advances, [S. l.], v. 35, n. 2, p. 217-239, 2017. DOI: 10.1016/j.biotechadv.2016.12.006. Disponível

em: http://dx.doi.org/10.1016/j.biotechadv.2016.12.006.

HOWARD, Daniel; BUTTERY, Lee D.; SHAKESHEFF, Kevin M.; ROBERTS, Scott J. Tissue engineering: Strategies, stem cells and scaffolds. Journal of Anatomy, [S. l.], v. 213, n. 1, p. 66-72, 2008. DOI: 10.1111/j.1469-7580.2008.00878.x.

HRIBAR, Kolin C.; SOMAN, Pranav; WARNER, John; CHUNG, Peter; CHEN, Shaochen. Light-assisted direct-write of 3D functional biomaterials. Lab on a Chip, [S. l.], v. 14, n. 2, p. 268-275, 2014. DOI: 10.1039/c3lc50634g.

HUANG, Boyang; BÁRTOLO, Paulo Jorge. Rheological characterization of polymer/ceramic blends for $3 \mathrm{D}$ printing of bone scaffolds. Polymer Testing, [S. l.], v. 68, p. 365-378, 2018. DOI: 10.1016/j.polymertesting.2018.04.033. Disponível em: https://doi.org/10.1016/j.polymertesting.2018.04.033.

HUTCHINGS, Ian. Impressão Jato de Tinta para Decoração de Revestimentos Cerâmicos: Tecnologia e Oportunidades. Cerâmica Industrial, [S. l.], v. 15, n. 2, p. 7-14, 2010.

HUTMACHER, Dietmar W.; SCHANTZ, Thorsten; ZEIN, Iwan; NG, Kee Woei; TEOH, Swee Hin; TAN, Kim Cheng. Mechanical properties and cell cultural response of polycaprolactone scaffolds designed and fabricated via fused deposition modeling. Journal of Biomedical Materials Research, [S. l.], v. 55, n. 2, p. 203-216, 2001. DOI: $10.1002 / 1097-4636(200105) 55: 2<203:: A I D-$

JBM1007>3.0.CO;2-7.

HUTSON, Che B.; NICHOL, Jason W.; AUBIN, Hug; BAE, Hojae; YAMANLAR, Seda; AL-HAQUE, Shahed; KOSHY, Sandeep T.; KHADEMHOSSEINI, Ali. Synthesis and characterization of tunable poly(ethylene glycol): Gelatin methacrylate composite hydrogels. Tissue Engineering - Part A, $[S$. l.], v. 17 , n. 13-14, p. 1713-1723, 2011. DOI: 10.1089/ten.tea.2010.0666.

ISRAELACHVILI, Jacob N. Intermolecular and Surface Forces. [s.1: s.n.]. v. 1 
JAKUS, Adam E.; RUTZ, Alexandra L.; SHAH, Ramille N.; AL, Et. Advancing the field of $3 \mathrm{D}$ biomaterial printing. Biomedical Materials (Bristol), [S. l.], v. 11, n. 1, p. 1-11, 2016. DOI: 10.1088/1748-6041/11/1/014102. Disponível em: http://dx.doi.org/10.1088/1748-6041/11/1/014102.

JANG, Jinah; SEOL, Young Joon; KIM, Hyeon Ji; KUNDU, Joydip; KIM, Sung Won; CHO, Dong Woo. Effects of alginate hydrogel cross-linking density on mechanical and biological behaviors for tissue engineering. Journal of the Mechanical Behavior of Biomedical Materials, [S. l.], v. 37, p. 69-77, 2014. DOI: 10.1016/j.jmbbm.2014.05.004. Disponível em: http://dx.doi.org/10.1016/j.jmbbm.2014.05.004.

JANMEY, Paul A.; WINER, Jessamine P.; WEISEL, John W.; AL, Et. Fibrin gels and their clinical and bioengineering applications. Journal of the Royal Society Interface, [S. l.], v. 6, n. 30, p. 1-10, 2009. DOI: 10.1098/rsif.2008.0327.

JIN, Rong; DIJKSTRA, Pieter J. Hydrogels for Tissue Engineering. In: Biomedical Applications of Hydrogels Handbook. [s.1: s.n.]. p. 203-225. DOI: 10.1007/978-1-44195919-5.

JOCKENHOEVEL, Stefan; ZUND, Gregor; HOERSTRUP, Simon P.; CHALABI, Khaled; SACHWEH, Jörg S.; DEMIRCAN, Lütfü; MESSMER, Bruno J.; TURINA, Marko. Fibrin gel - advantages of a new scaffold in cardiovascular tissue engineering. European Journal of Cardio-thoracic Surgery, [S. l.], v. 19, n. 4, p. 424-430, 2001. DOI: 10.1016/S10107940(01)00624-8.

JOHNSON, Blake N. et al. 3D Printed Anatomical Nerve Regeneration Pathways. Advanced Functional Materials, [S. l.], v. 25, n. 39, p. 6205-6217, 2015. DOI: 10.1002/adfm.201501760.

JOHNSON, McKayla Brianne. The Effect of Ultraviolet Light on Cell Viability, DNA Damage and Repair in HutchinsonGilford Progeria Syndrome and BJ Fibroblasts. [S. l.], p. 1-34, 2011. Disponível em: http://honors.epub.etsu.edu/92/1/MJohnson_2011_Final_Thesi s.pdf.

JUNG, Sungjune. Fluid characterisation and drop impact in inkjet printing for organic semiconductor devices. 2011. [S. l.], 2011. Disponível em: http://www.dspace.cam.ac.uk/bitstream/1810/241610/1/PhD

Thesis - Sungjune Jung.pdf.

JUNGST, Tomasz; SMOLAN, Willi; SCHACHT, Kristin; SCHEIBEL, Thomas; GROLL, Jürgen. Strategies and Molecular Design Criteria for 3D Printable Hydrogels. Chemical Reviews, [S. l.], v. 116, n. 3, p. 1496-1539, 2016. DOI: 10.1021/acs.chemrev.5b00303.

KANG, Hyun Wook; LEE, Sang Jin; KO, In Kap; KENGLA, Carlos; YOO, James J.; ATALA, Anthony. A 3D bioprinting system to produce human-scale tissue constructs with structural integrity. Nature Biotechnology, [S. l.], v. 34, n. 3, 2016. DOI: 10.1038/nbt.3413.

KAULLY, Tamar; KAUFMAN-FRANCIS, Keren; LESMAN, Ayelet; LEVENBERG, Shulamit. Vascularization - the conduit to viable engineered tissues. Tissue Engineering - Part B: Reviews, [S. l.], v. 15, n. 2, p. 159-169, 2009. DOI: 10.1089/ten.teb.2008.0193.

KAZEMIAN, Sina; PRASAD, Arun; HUAT, Bujang B. K.; MOHAMMED, Thamer A.; ABDUL AZIZ, Farah N. A. Effect of cement, sodium silicate, kaolinite and water on the viscosity of the grout. Scientific Research and Essays, [S. l.], v. 5, n. 22, p. 3434-3442, 2010.

KEBEDE, Mekuriaw A.; ASIKU, Karen Sabrina; IMAE,
Toyoko; KAWAKAMI, Masaru; FURUKAWA, Hidemitsu; WU, Chang Mou. Stereolithographic and molding fabrications of hydroxyapatite-polymer gels applicable to bone regeneration materials. Journal of the Taiwan Institute of Chemical Engineers, [S. l.], v. 92, p. 91-96, 2018. DOI: 10.1016/j.jtice.2018.01.034. Disponível em: https://doi.org/10.1016/j.jtice.2018.01.034.

KESTI, Matti; EBERHARDT, Christian; PAGLICCIA, Guglielmo; KENKEL, David; GRANDE, Daniel; BOSS, Andreas; ZENOBI-WONG, Marcy. Bioprinting Complex Cartilaginous Structures with Clinically Compliant Biomaterials. Advanced Functional Materials, [S. l.], v. 25, n. 48, p. 7406-7417, 2015. DOI: 10.1002/adfm.201503423.

KHANSARI, Maziyar M.; SOROKINA, Lioudmila V.; MUKHERJEE, Prithviraj; MUKHTAR, Farrukh; SHIRDAR, Mostafa Rezazadeh; SHAHIDI, Mahnaz; SHOKUHFAR, Tolou. Classification of Hydrogels Based on Their Source: A Review and Application in Stem Cell Regulation. Jom, [S. l.], v. 69 , n. 8 , p. $1340-1347,2017$. DOI: $10.1007 / \mathrm{s} 11837-017-$ 2412-9.

KIM, Byoung Soo; LEE, Jung-Seob; GAO, Ge; CHO, DongWoo; CUBO, Nieves; GARCIA, Marta; DEL CAÑIZO, Juan F. Direct 3D cell-printing of human skin with functional transwell system 3D bioprinting of functional human skin: production and in vivo analysis. Biofabrication, [S. l.], v. 9, n. 2, p. 1-12, 2017. DOI: $\quad 10.1088 / 1758-5090 / a a 71 c 8 . \quad$ Disponível em: http://stacks.iop.org/1758-

$5090 / 9 / \mathrm{i}=2 / \mathrm{a}=025034$ ? $\mathrm{key}=$ crossref. $4 \mathrm{f} 5 \mathrm{f} 460578 \mathrm{bb5c3ae0056d}$ c668609ef6.

$\mathrm{KOCH}$, Lothar et al. Laser printing of skin cells and human stem cells. Tissue Engineering - Part C: Methods, [S. l.], v. 16, n. 5, p. 847-854, 2010. DOI: 10.1089/ten.tec.2009.0397.

KOLESKY, David B.; HOMAN, Kimberly A.; SKYLARSCOTT, Mark A.; LEWIS, Jennifer A. Three-dimensional bioprinting of thick vascularized tissues. Proceedings of the National Academy of Sciences of the United States of America, [S. l.], v. 113, n. 12, p. 3179-3184, 2016. DOI: 10.1073/pnas.1521342113.

KOLESKY, David B.; TRUBY, Ryan L.; GLADMAN, A. Sydney; BUSBEE, Travis A.; HOMAN, Kimberly A.; LEWIS, Jennifer A. 3D bioprinting of vascularized, heterogeneous cellladen tissue constructs. Advanced Materials, [S. l.], v. 26, n. 19, p. 3124-3130, 2014. DOI: 10.1002/adma.201305506.

KÖLLMER, Melanie; KESKAR, Vandana; HAUK, Thomas G.; COLLINS, John M.; RUSSELL, Brenda; GEMEINHART, Richard A. Stem cell-derived extracellular matrix enables survival and multilineage differentiation within superporous hydrogels. Biomacromolecules, [S. l.], v. 13, n. 4, p. 963-973, 2012. DOI: $10.1021 / \mathrm{bm} 300332 \mathrm{w}$.

KULKARNI, Vitthal S.; SHAW, Charles. Rheological Studies. [s.1: s.n.]. DOI: 10.1016/b978-0-12-801024-2.00009-1.

KUO, Catherine K.; MA, Peter X. Ionically crosslinked alginate hydrogels as scaffolds for tissue engineering: Part 1. Structure, gelation rate and mechanical properties. Biomaterials, [S. l.], v. 22 , n. 6, p. 511-521, 2001. DOI: 10.1016/S01429612(00)00201-5.

LAFTAH, Waham Ashaier; HASHIM, Shahrir; IBRAHIM, Akos N. Polymer hydrogels: A review. Polymer - Plastics Technology and Engineering, [S. l.], v. 50, n. 14, p. 14751486, 2011. DOI: 10.1080/03602559.2011.593082.

LANGER, Robert; VACANTI, Joseph P. Tissue Engineering. Educational Forum, [S. l.], v. 260, n. 1, p. 920-926, 1993. LEE, Kuen Yong; MOONEY, David J. Hydrogels for tissue 
engineering. Chemical Reviews, [S. l.], v. 101, n. 7, p. 18691879, 2001. DOI: 10.1021/cr000108x.

LEE, Kuen Yong; MOONEY, David J. Alginate: Properties and biomedical applications. Progress in Polymer Science (Oxford), [S. l.], v. 37, n. 1, p. 106-126, 2012. DOI: 10.1016/j.progpolymsci.2011.06.003. Disponível em: http://dx.doi.org/10.1016/j.progpolymsci.2011.06.003.

LETOURNEAU, CA; DAVIES, CT; TABIBKHOEI, F.; DAUBERT, GL; BECK, JM; SCHRYBER, JW; QUINN, TZ. 3D Printing of Medical Devices: When a Novel Technology Meets Traditional Legal Principles. Reed Smith, [S. l.], v. 1, n. 1, p. 5-9, 2015. DOI: 10.1007/BF03165945.

LI, Jinhua; WU, Chengtie; CHU, Paul K.; GELINSKY, Michael; AL, Et. 3D printing of hydrogels: Rational design strategies and emerging biomedical applications. Materials Science and Engineering R: Reports, [S. l.], v. 140, p. 1-76, 2020. DOI: 10.1016/j.mser.2020.100543. Disponível em: https://doi.org/10.1016/j.mser.2020.100543.

LI, P. 3D bioprinting: Regulation, innovation, and patents. 3D Bioprinting for Reconstructive Surgery: Techniques and Applications, [S. l.], p. 217-231, 2018. DOI: 10.1016/B978-008-101103-4.00020-X.

LIND, Johan U. et al. Instrumented cardiac microphysiological devices via multimaterial three-dimensional printing. Nature Materials, [S. l.], v. 16, n. 3, p. 303-308, 2017. DOI: 10.1038/nmat4782.

LIU, Hongjun; LI, Yamin; LI, Dongjian; AL., Et. Research on rheological properties and extrusion behavior of aqueous alumina paste in paste-extrusion-based SFF processes. International Journal of Advanced Manufacturing Technology, [S. l.], v. 83, n. 9-12, p. 2039-2047, 2016. DOI: 10.1007/s00170-015-7720-z.

LIU, Pengfei; PENG, Jing; LI, Jiuqiang; WU, Jilan. Radiation crosslinking of CMC-Na at low dose and its application as substitute for hydrogel. Radiation Physics and Chemistry, [S. l.], v. $72, \quad$ n. $5, \quad$ p. 635-638, 2005. DOI: 10.1016/j.radphyschem.2004.03.090.

LIU, Pengfei; ZHAI, Maolin; LI, Jiuqiang; PENG, Jing; WU, Jilan. Radiation preparation and swelling behavior of sodium carboxymethyl cellulose hydrogels. Radiation Physics and Chemistry, [S. l.], v. 63, n. 3-6, p. 525-528, 2002. DOI: 10.1016/S0969-806X(01)00649-1.

LUTOLF, Matthias P.; RAEBER, George P.; ZISCH, Andreas H.; TIRELLI, Nicola; HUBBELL, Jeffrey A. Cell-responsive synthetic hydrogels. Advanced Materials, [S. l.], v. 15, n. 11, p. 888-892, 2003. DOI: 10.1002/adma.200304621.

MAITRA, Jaya; SHUKLA, Vivek Kumar. Cross-linking in Hydrogels - A Review. American Journal of Polymer Science, [S. l.], v. 4, n. 2, p. 25-31, 2014. DOI: 10.5923/j.ajps.20140402.01.

MALDA, Jos; VISSER, Jetze; MELCHELS, Ferry P.; JÜNGST, Tomasz; HENNINK, Wim E.; DHERT, Wouter J. A.; GROLL, Jürgen; HUTMACHER, Dietmar W. 25th anniversary article: Engineering hydrogels for biofabrication. Advanced Materials, [S. l.], v. 25, n. 36, p. 5011-5028, 2013. DOI: 10.1002/adma.201302042.

MANDRYCKY, Christian; WANG, Zongjie; KIM, Keekyoung; KIM, Deok Ho. 3D bioprinting for engineering complex tissues. Biotechnology Advances, [S. l.], v. 34, n. 4, p. 422-434, 2016. DOI: 10.1016/j.biotechadv.2015.12.011. Disponível

http://dx.doi.org/10.1016/j.biotechadv.2015.12.011.

MARKLEIN, Ross A.; BURDICK, Jason A. Controlling stem cell fate with material design. Advanced Materials, [S. l.], v. 22, n. 2, p. 175-189, 2010. DOI: 10.1002/adma.200901055.

MARTIN, Graham D.; HOATH, Stephen D.; HUTCHINGS, Ian M.; AL, Et. Inkjet printing - The physics of manipulating liquid jets and drops. Journal of Physics: Conference Series, [S. l.], v. 105, n. 1, 2008. DOI: 10.1088/17426596/105/1/012001.

MASUTANI, Evan M.; KINOSHITA, Christopher K.; TANAKA, Travis T.; ELLISON, Andrew K. D.; YOZA, Brandon A. Increasing thermal stability of gelatin by UVinduced cross-linking with glucose. International Journal of Biomaterials, $\quad[S . \quad$ l.,$\quad$ v. 2014, 2014. DOI: 10.1155/2014/979636.

MCHUGH, Dennis. Production and utilization of products from commercial seaweeds. FAO.org, [S. l.], p. 1-32, 1987. Disponível em:

http://www.fao.org/docrep/x5822e/x5822e03.htm.

MILLON, Leonardo E.; PADAVAN, Donna T.; HAMILTON, Amanda M.; BOUGHNER, Derek R.; WAN, Wankei. Exploring cell compatibility of a fibronectin-functionalized physically crosslinked poly(vinyl alcohol) hydrogel. Journal of Biomedical Materials Research - Part B Applied Biomaterials, [S. l.], v. 100 B, n. 1, p. 1-10, 2012. DOI: 10.1002/jbm.b.31860.

MIN, Daejin; LEE, Wonhye; BAE, Il-Hong; LEE, Tae Ryong; CROCE, Phillip; YOO, Seung Schik. Bioprinting of Biomimetic Skin containing Melanocytes. Experimental Dermatology, [S. l.], v. 27, n. 5, p. 453-459, 2017. DOI: 10.1111/exd.13376.

MOFFAT, Kristen L.; WANG, I. Ning Elaine; RODEO, Scott A.; LU, Helen H. Orthopedic Interface Tissue Engineering for the Biological Fixation of Soft Tissue Grafts. Clinics in Sports Medicine, [S. l.], v. 28, n. 1, p. 157-176, 2009. DOI: 10.1016/j.csm.2008.08.006.

MOL, Anita; VAN LIESHOUT, Marjolein I.; DAM-DE VEEN, Christa G.; NEUENSCHWANDER, Stefan; HOERSTRUP, Simon P.; BAAIJENS, Frank P. T.; BOUTEN, Carlijn V. C. Fibrin as a cell carrier in cardiovascular tissue engineering applications. Biomaterials, [S. l.], v. 26, n. 16, p. 3113-3121, 2005. DOI: 10.1016/j.biomaterials.2004.08.007.

MORRISON, Faith A. Understandig Rheology. New York: Oxford University Press, 2001. Disponível em: https://global.oup.com/ushe/product/understanding-rheology9780195141665 ?cc=us\&lang=en\&.

MÜLLER, Michael; BECHER, Jana; SCHNABELRAUCH, Matthias; ZENOBI-WONG, Marcy. Nanostructured Pluronic hydrogels as bioinks for 3D bioprinting. Biofabrication, [S. l.], v. 7, n. 3, p. 35006, 2015. DOI: 10.1088/1758-5090/7/3/035006. Disponível em: http://dx.doi.org/10.1088/17585090/7/3/035006.

NAGASAWA, Naotsugu; YAGI, Toshiaki; KUME, Tamikazu; YOSHII, Fumio. Radiation crosslinking of carboxymethyl starch. Carbohydrate Polymers, [S. l.], v. 58, n. 2, p. 109-113, 2004. DOI: 10.1016/j.carbpol.2004.04.021.

NAIR, Kalyani; GANDHI, Milind; KHALIL, Saif; YAN, Karen Chang; MARCOLONGO, Michele; BARBEE, Kenneth; SUN, Wei. Characterization of cell viability during bioprinting processes. Biotechnology Journal, [S. l.], v. 4, n. 8, p. 11681177, 2009. DOI: 10.1002/biot.200900004.

NICHOL, Jason W.; KOSHY, Sandeep T.; BAE, Hojae; HWANG, Chang M.; YAMANLAR, Seda; KHADEMHOSSEINI, Ali. Cell-laden microengineered gelatin methacrylate hydrogels. Biomaterials, [S. l.], v. 31, n. 21, p. 5536-5544, 2010. DOI: 10.1016/j.biomaterials.2010.03.064. 
Disponível

http://dx.doi.org/10.1016/j.biomaterials.2010.03.064.

NORMAND, Valéry; LOOTENS, Didier L.; AMICI, Eleonora; PLUCKNETT, Kevin P.; AYMARD, Pierre. New insight into agarose gel mechanical properties. Biomacromolecules, [S. l.], v. 1, n. 4, p. 730-738, 2000. DOI: 10.1021/bm005583j.

OLSEN, David et al. Recombinant collagen and gelatin for drug delivery. Advanced Drug Delivery Reviews, [S. l.], v. 55, n. 12, p. 1547-1567, 2003. DOI: 10.1016/j.addr.2003.08.008. OSSWALD, Tim A.; RUDOLPH, Natalie. Polymer Rheology. [s.1.] : Hanser Publications, 2015. a. DOI: 10.1002/app.1961.070051418.

OSSWALD, Tim A.; RUDOLPH, Natalie. Polymer Rheology. Munich: Hanser Publishers, 2015. b. Disponível em: http://www.eng.utoledo.edu/coe/polymer/courses/pdfs/rheolog y.pdf.

OUYANG, Liliang; HIGHLEY, Christopher B.; RODELL, Christopher B.; SUN, Wei; BURDICK, Jason A. 3D Printing of Shear-Thinning Hyaluronic Acid Hydrogels with Secondary Cross-Linking. ACS Biomaterials Science and Engineering, [S. l.], v. 2, n. 10, p. 1743-1751, 2016. a. DOI: 10.1021/acsbiomaterials.6b00158.

OUYANG, Liliang; YAO, Rui; ZHAO, Yu; SUN, Wei. Effect of bioink properties on printability and cell viability for $3 \mathrm{D}$ bioplotting of embryonic stem cells. Biofabrication, [S. l.], v. 8, n. 3, p. 1-12, 2016. b. DOI: 10.1088/1758-5090/8/3/035020. Disponível em: http://dx.doi.org/10.1088/17585090/8/3/035020.

PALEOS, George A. What are Hydrogels ? Pittsburgh Plastics Manufacturing, Butler, PA, [S. l.], p. 1-4, 2012. DOI: 10.1021/ma502133f

PEPPAS, N. A.; BURES, P.; LEOBANDUNG, W.; ICHIKAWA, H. Hydrogels in pharmaceutical formulations. European Journal of Pharmaceutics and Biopharmaceutics, [S. l.], v. 50, n. 1, p. 27-46, 2000. DOI: 10.1016/S09396411(00)00090-4.

QIU, Yong; PARK, Kinam. Environment-sensitive hydrogels for drug delivery. Advanced Drug Delivery Reviews, [S. l.], v. 53, p. 321-339, 2001. DOI: 10.1111/j.14401819.1998.tb00997.x.

RAHEJA, Leah F.; GALUPPO, Larry D.; BOWERS-LEPORE, Jeanne; DOWD, Joseph P.; TABLIN, Fern; YELLOWLEY, Clare E. Treatment of Bilateral Medial Femoral Condyle Articular Cartilage Fissures in a Horse Using Bone MarrowDerived Multipotent Mesenchymal Stromal Cells. Journal of Equine Veterinary Science, [S. l.], v. 31, n. 3, p. 147-154, 2011. DOI: 10.1016/j.jevs.2010.12.009. Disponível em: http://dx.doi.org/10.1016/j.jevs.2010.12.009.

RAJANGAM, Thanavel; AN, Seong Soo A. Fibrinogen and fibrin based micro and nano scaffolds incorporated with drugs, proteins, cells and genes for therapeutic biomedical applications. International Journal of Nanomedicine, [S. l.], v. 8, p. 3641-3662, 2013. DOI: 10.2147/IJN.S43945.

RIOBOO, R.; MARENGO, M.; TROPEA, C.; AL, Et. Time evolution of liquid drop impact onto solid, dry surfaces. Experiments in Fluids, [S. l.], v. 33, n. 1, p. 112-124, 2002. DOI: $10.1007 / \mathrm{s} 00348-002-0431-\mathrm{x}$.

RIOBOO, R.; TROPEA, Cam; MARENGO, M.; AL, Et. Outcomes from a drop impact on solid surfaces. Atomization and Sprays, [S. l.], v. 11, n. 2, p. 155-165, 2001. DOI: 10.1615/atomizspr.v11.i2.40.

RIVKIN, Rachel; BEN-ARI, Alon; KASSIS, Ibrahim; ZANGI, Lior; GABERMAN, Elena; LEVDANSKY, Lilia; MARX,
Gerard; GORODETSKY, Raphael. High-yield isolation, expansion, and differentiation of murine bone marrow-derived mesenchymal stem cells using fibrin microbeads (FMB). Cloning and Stem Cells, [S. l.], v. 9, n. 2, p. 157-175, 2007. DOI: 10.1089/clo.2006.0039.

ROGERS, Simon. Large amplitude oscillatory shear: Simple to describe, hard to interpret. Physics Today, [S. l.], v. 71, n. 7, p. 34-40, 2018. DOI: 10.1063/PT.3.3971.

ROGERS, Simon A.; LETTINGA, M. Paul. A sequence of physical processes determined and quantified in large-amplitude oscillatory shear (LAOS): Application to theoretical nonlinear models. Journal of Rheology, [S. l.], v. 56, n. 1, p. 1-25, 2012. DOI: 10.1122/1.3662962.

RUTZ, Alexandra L.; HYLAND, Kelly E.; JAKUS, Adam E.; BURGHARDT, Wesley R.; SHAH, Ramille N. A multimaterial bioink method for 3D printing tunable, cell-compatible hydrogels. Advanced Materials, [S. l.], v. 27, n. 9, p. 16071614, 2015. DOI: 10.1002/adma.201405076.

SALINAS, C. N.; ANSETH, K. S. Mesenchymal stem cells for craniofacial tissue regeneration: Designing hydrogel delivery vehicles. Journal of Dental Research, [S. l.], v. 88, n. 8, p. 681-692, 2009. DOI: 10.1177/0022034509341553.

SÁNCHEZ, JOSÉ LUIS DÁVILA. Rheological studies and 3D extrusion-based printing of nanocomposite hydrogels Estudos reológicos e impressão 3D baseada em extrusão de hidrogéis nanocompósitos Rheological studies and 3D extrusion-based printing of nanocomposite hydrogels Estudos reológi. 2018. [S. l.], 2018.

SCHMEDLEN, Rachael H.; MASTERS, Kristyn S.; WEST, Jennifer L.; AL, Et. Photocrosslinkable polyvinyl alcohol hydrogels. Biomaterials, [S. l.], v. 23, p. 4325-4332, 2002. DOI: 10.1016/S0142-9612(02)00177-1.

SCHUURMAN, Wouter; LEVETT, Peter A.; POT, Michiel W.; VAN WEEREN, Paul René; DHERT, Wouter J. A.; HUTMACHER, Dietmar W.; MELCHELS, Ferry P. W.; KLEIN, Travis J.; MALDA, Jos. Gelatin-methacrylamide hydrogels as potential biomaterials for fabrication of tissueengineered cartilage constructs. Macromolecular Bioscience, [S. l.], v. 13, n. 5, p. 551-561, 2013. DOI: 10.1002/mabi.201200471.

SHAFIEE, Ashkan et al. Physics of bioprinting. Applied Physics Reviews, [S. l.], v. 6, n. 2, 2019. DOI: 10.1063/1.5087206.

SINGH, Satnam; CHOUDHURY, Deepak; YU, Fang; MIRONOV, Vladimir; NAING, May Win. In situ bioprinting Bioprinting from benchside to bedside? Acta Biomaterialia, [S. l.], v. 101, n. $\operatorname{xxxx,}$ p. 14-25, 2020. DOI: 10.1016/j.actbio.2019.08.045. Disponível em: https://doi.org/10.1016/j.actbio.2019.08.045.

SKARDAL, Aleksander; MACK, David; KAPETANOVIC, Edi; ATALA, Anthony; JACKSON, John D.; YOO, James; SOKER, Shay; AL, Et. Bioprinted Amniotic Fluid-Derived Stem Cells Accelerate Healing of Large Skin Wounds. Stem Cells Translational Medicine, [S. l.], p. 792-802, 2012.

SKARDAL, Aleksander; ZHANG, Jianxing; PRESTWICH, Glenn D. Bioprinting vessel-like constructs using hyaluronan hydrogels crosslinked with tetrahedral polyethylene glycol tetracrylates. Biomaterials, [S. l.], v. 31, n. 24, p. 6173-6181, 2010. DOI: 10.1016/j.biomaterials.2010.04.045. Disponível em: http://dx.doi.org/10.1016/j.biomaterials.2010.04.045.

SLAUGHTER, Brandon V.; KHURSHID, Shahana S.; FISHER, Omar Z.; KHADEMHOSSEINI, Ali; PEPPAS, Nicholas A. Hydrogels in regenerative medicine. Advanced 
Materials, [S. l.], v. 21, n. 32-33, p. 3307-3329, 2009. DOI: 10.1002/adma.200802106.

SMITH, Cynthia M.; STONE, Alice L.; PARKHILL, Robert L.; STEWART, Robert L.; SIMPKINS, Mark W.; KACHURIN, Anatoly M.; WARREN, William L.; WILLIAMS, Stuart K. Three-dimensional bioassembly tool for generating viable tissue-engineered constructs. Tissue Engineering, [S. l.], v. 10, n. 9-10, p. 1566-1576, 2004. DOI: 10.1089/ten.2004.10.1566. SPERINDE, Jeffrey J.; GRIFFITH, Linda G. Synthesis and characterization of enzymatically-cross-linked poly(ethylene glycol) hydrogels. Macromolecules, [S. l.], v. 30, n. 18, p. 5255-5264, 1997. DOI: 10.1021/ma970345a.

STRUBLE, Leslie J.; JI, Xihuang. Rheology. In: Handbook of Analytical Techniques in Concrete Science and Technology: Principles, Techniques and Applications. 1. ed. [s.1.] : William Andrew, 2002. p. 333-367.

SU, Kai; WANG, Chunming. Recent advances in the use of gelatin in biomedical research. Biotechnology Letters, [S. l.], v. 37 , n. 11 , p. $2139-2145$, 2015. DOI: $10.1007 / \mathrm{s} 10529-015-$ 1907-0.

TOWNSEND, Jakob M.; BECK, Emily C.; GEHRKE, Stevin H.; BERKLAND, Cory J.; DETAMORE, Michael S. Flow behavior prior to crosslinking: The need for precursor rheology for placement of hydrogels in medical applications and for 3D bioprinting. Progress in Polymer Science, [S. l.], v. 91, p. 126140, 2019. DOI: 10.1016/j.progpolymsci.2019.01.003. Disponível

https://doi.org/10.1016/j.progpolymsci.2019.01.003.

TRACHTENBERG, Jordan E.; MOUNTZIARIS, Paschalia M.; MILLER, Jordan S.; WETTERGREEN, Matthew; KASPER, Fred K.; MIKOS, Antonios G. Open-source three-dimensional printing of biodegradable polymer scaffolds for tissue engineering. Journal of Biomedical Materials Research Part A, [S. l.], v. 102, n. 12, p. 4326-4335, 2014. DOI: 10.1002/jbm.a.35108.

TSAI, M. H.; HWANG, W. S.; CHOU, H. H.; HSIEH, P. H. Effects of pulse voltage on inkjet printing of a silver nanopowder suspension. Nanotechnology, [S. l.], v. 19, n. 33 , 2008. DOI: 10.1088/0957-4484/19/33/335304.

TSIHLIS, Nick D.; MURAR, Jozef; KAPADIA, Muneera R.; AHANCHI, Sadaf S.; OUSTWANI, Christopher S.; SAAVEDRA, Joseph E.; KEEFER, Larry K.; KIBBE, Melina R. Hydrogels: Methods of Preparation. Journal of Vascular Surgery, [S. l.], v. 51, n. 5, p. 1248-1259, 2010. DOI: 10.1016/j.jvs.2009.12.028. Disponível

http://www.ncbi.nlm.nih.gov/pubmed/20223627.

TSUJI, Hideto; HORII, Fumitaka; HYON, Suong Hyu; IKADA, Yoshito. Stereocomplex Formation between Enantiomeric Poly(lactic acid)s. 2. Stereocomplex Formation in Concentrated Solutions. Macromolecules, [S. l.], v. 24, n. 10, p. 2719-2724, 1991. DOI: 10.1021/ma00010a013.

VALLÉS, E.; DURANDO, D.; KATIME, I.; MENDIZÁBAL, E.; PUIG, J. E. Equilibrium swelling and mechanical properties of hydrogels of acrylamide and itaconic acid or its esters. Polymer Bulletin, [S. l.], v. 44, n. 1, p. 109-114, 2000. DOI: 10.1007/s002890050580.

WANG, Shuai; LEE, Jia Min; YEONG, Wai Yee. Smart hydrogels for 3D bioprinting. International Journal of Bioprinting, $[S$. l.], v. 1, n. 1, p. 3-14, 2015. DOI: 10.18063/IJB.2015.01.005.

WANG, Wei; LI, Dan; WANG, Mei Cong; LI, Yang Lin; GAO, Chang You. A hybrid scaffold of poly(lactide-co-glycolide) sponge filled with fibrin gel for cartilage tissue engineering.
Chinese Journal of Polymer Science (English Edition), [S. l.], v. 29, n. 2, p. 233-240, 2011. DOI: 10.1007/s10118-010-10262.

WANG, X.; AO, Q.; TIAN, Xiaohong; FAN, Jun; TONG, Hao; HOU, Weijian; BAI, Shuling; AL, Et. Gelatin-based hydrogels for organ 3D bioprinting. Polymers, [S. l.], v. 9, n. 9, 2017. DOI: $10.3390 /$ polym9090401.

WANG, Zheng-yu; ZHANG, Qing-zhi; KONNO, Mikio; SAITO, Shozaburo. Sol-Gel Transition of Alginate Solution by the Addition of. [S. l.], 1994.

WEBER, Gregor Cornelius; BUHREN, Bettina Alexandra; SCHRUMPF, Holger; WOHLRAB, Johannes; GERBER, Peter Arne. Clinical applications of hyaluronidase. Advances in Experimental Medicine and Biology, [S. l.], v. 1148, p. 255277, 2019. DOI: 10.1007/978-981-13-7709-9_12.

WILHELM, Manfred. Fourier-Transform Rheology. Macromolecular Materials and Engineering, [S. l.], v. 287, n. 2 , p. 83 , 2002. DOI: $10.1002 / 1439-$ 2054(20020201)287:2<83::aid-mame83>3.3.co;2-2.

WONG, Kaufui V.; HERNANDEZ, Aldo. A Review of Additive Manufacturing. ISRN Mechanical Engineering, [S. l.], v. 2012, p. 1-10, 2012. DOI: 10.5402/2012/208760.

WÜST, Silke; MÜLLER, Ralph; HOFMANN, Sandra. 3D Bioprinting of complex channels - Effects of material, orientation, geometry, and cell embedding. Journal of Biomedical Materials Research - Part A, [S. l.], v. 103, n. 8, p. 2558-2570, 2015. DOI: 10.1002/jbm.a.35393.

YANG, Xingchen; LU, Zhenhui; WU, Huayu; LI, Wei; ZHENG, Li; ZHAO, Jinmin. Collagen-alginate as bioink for three-dimensional (3D) cell printing based cartilage tissue engineering. Materials Science and Engineering C, [S. l.], v. 83, n. June, p. 195-201, 2018. DOI: 10.1016/j.msec.2017.09.002. Disponível em: http://dx.doi.org/10.1016/j.msec.2017.09.002.

YOUNG, Simon; WONG, Mark; TABATA, Yasuhiko; MIKOS, Antonios G. Gelatin as a delivery vehicle for the controlled release of bioactive molecules. Journal of Controlled Release, [S. l.], v. 109, n. 1-3, p. 256-274, 2005. DOI: 10.1016/j.jconrel.2005.09.023.

ZAFAR, Muhammad Qasim; ZHAO, Haiyan. 4D Printing: Future Insight in Additive Manufacturing. Metals and Materials International, [S. l.], v. 26, n. 5, p. 564-585, 2020. DOI: $\quad 10.1007 / \mathrm{s} 12540-019-00441-w . \quad$ Disponível em: https://doi.org/10.1007/s12540-019-00441-w.

ZAVAN, Barbara; CORTIVO, Roberta; ABATANGELO, Giovanni; AL, Et. Hydrogels and Tissue Engineering. In: Hydrogels: Biological Properties and Applications. [s.l: s.n.]. p. $1-8$.

ZHANG, Lijie Grace; FISHER, John P.; LEONG, Kam W.; AL, Et. 3D Bioprinting and Nanotechnology in Tissue Engineering and Regenerative Medicine. [s.l: s.n.]. DOI: 10.1016/C2013-0-18595-9.

ZHANG, Zhanpeng; EYSTER, Thomas W.; MA, Peter X.; AL, Et. Nanostructured injectable cell microcarriers for tissue regeneration. Nanomedicine, [S. l.], v. 11, n. 12, p. 1611-1628, 2016. a. DOI: 10.2217/nnm-2016-0083.

ZHANG, Zhengyi; XIONG, Ruitong; CORR, David T.; HUANG, Yong. Study of Impingement Types and Printing Quality during Laser Printing of Viscoelastic Alginate Solutions. Langmuir, [S. l.], v. 32, n. 12, p. 3004-3014, 2016. b. DOI: 10.1021/acs.langmuir.6b00220.

ZHANG, Zhengyi; XIONG, Ruitong; MEI, Renwei; HUANG, Yong; CHRISEY, Douglas B. Time-Resolved Imaging Study of 
Jetting Dynamics during Laser Printing of Viscoelastic Alginate Solutions. Langmuir, [S. l.], v. 31, n. 23, p. 6447-6456, 2015. b. DOI: 10.1021/acs.langmuir.5b00919.

ZHAO, Long; MITOMO, Hiroshi; ZHAI, Maolin; YOSHII, Fumio; NAGASAWA, Naotsugu; KUME, Tamikazu. Synthesis of antibacterial PVA/CM-chitosan blend hydrogels with electron beam irradiation. Carbohydrate Polymers, [S. l.], v. 53, n. 4, p. 439-446, 2003. DOI: 10.1016/S01448617(03)00103-6.

ZHAO, Qing Sheng; JI, Qiu Xia; XING, Ke; LI, Xiao Yan; LIU, Cheng Sheng; CHEN, Xi Guang. Preparation and characteristics of novel porous hydrogel films based on chitosan and glycerophosphate. Carbohydrate Polymers, [S. l.], v. 76, n. 3, p. 410-416, 2009. DOI: 10.1016/j.carbpol.2008.11.020. Disponível

em: http://dx.doi.org/10.1016/j.carbpol.2008.11.020.

ZHAO, Wen; JIN, Xing; CONG, Yang; LIU, Yuying; FU, Jun. Degradable natural polymer hydrogels for articular cartilage tissue engineering. Journal of Chemical Technology and Biotechnology, [S. l.], v. 88, n. 3, p. 327-339, 2013. DOI: 10.1002/jctb.3970.

ZHU, Junmin; MARCHANT, Roger E. Design properties of hydrogel tissue-engineering scaffolds. Expert Rev.Med.Devices, [S. l.], v. 8, n. 5, p. 607-626, 2011.

ZHU, Kai et al. Gold Nanocomposite Bioink for Printing 3D Cardiac Constructs. Advanced Functional Materials, [S. l.], v. 27, n. 12, p. 1-12, 2017. DOI: 10.1002/adfm.201605352. 